\title{
International Accounting Standards: Esperanto of Babylonische spraakverwarring?
}

Citation for published version (APA):

Vergoossen, R. G. A. (1999). International Accounting Standards: Esperanto of Babylonische spraakverwarring? Rede uitgesproken bij de aanvaarding van het ambt van hogleraar in de Bedrijfseconomie en Bedrijfskunde door Dr. R.G.A. Vergoossen RA. (1 ed.) Universiteit Maastricht. https://doi.org/10.26481/spe.19991029rv

Document status and date:

Published: 29/10/1999

DOI:

10.26481/spe.19991029rv

Document Version:

Publisher's PDF, also known as Version of record

\section{Please check the document version of this publication:}

- A submitted manuscript is the version of the article upon submission and before peer-review. There can be important differences between the submitted version and the official published version of record. People interested in the research are advised to contact the author for the final version of the publication, or visit the DOI to the publisher's website.

- The final author version and the galley proof are versions of the publication after peer review.

- The final published version features the final layout of the paper including the volume, issue and page numbers.

Link to publication

\footnotetext{
General rights rights.

- You may freely distribute the URL identifying the publication in the public portal. please follow below link for the End User Agreement:

www.umlib.nl/taverne-license

Take down policy

If you believe that this document breaches copyright please contact us at:

repository@maastrichtuniversity.nl

providing details and we will investigate your claim.
}

Copyright and moral rights for the publications made accessible in the public portal are retained by the authors and/or other copyright owners and it is a condition of accessing publications that users recognise and abide by the legal requirements associated with these

- Users may download and print one copy of any publication from the public portal for the purpose of private study or research.

- You may not further distribute the material or use it for any profit-making activity or commercial gain

If the publication is distributed under the terms of Article $25 \mathrm{fa}$ of the Dutch Copyright Act, indicated by the "Taverne" license above, 


\section{International Accounting Standards: Esperanto of Babylonische spraakverwarring?}

\section{Rede}

in verkorte vorm uitgesproken

bij de aanvaarding van het ambt van

hoogleraar in de Bedrijfseconomie en Bedrijfsunde in het bijzonder Internationale Externe Berichtgeving aan de Universiteit Maastricht op vrijdag 29 oktober 1999

door

Dr. R.G.A. Vergoossen RA

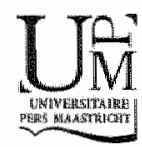


(C) R.G.A. Vergoossen, Naarden 1999

ISBN: 9052782695

Vormgeving en druk:

Datawyse || Universitaire Pers Maastricht 
Esperanto of Babylonische spraakverwarring? 13

Mijnheer de Rector Magnificus,

Zeer gewardeerde toehoorders.

Ik wil mijn inaugurele rede begimen met een kleine quiz.

In figuur la ziet $u$ het verloop van de nettowinst van Onderneming $X$ over de afgelopen vijftien jaar, dat wil zeggen de periode 1984-1998. U ziet dat de nettowinst van Onderneming $X$ in die periode trendmatig groeit.

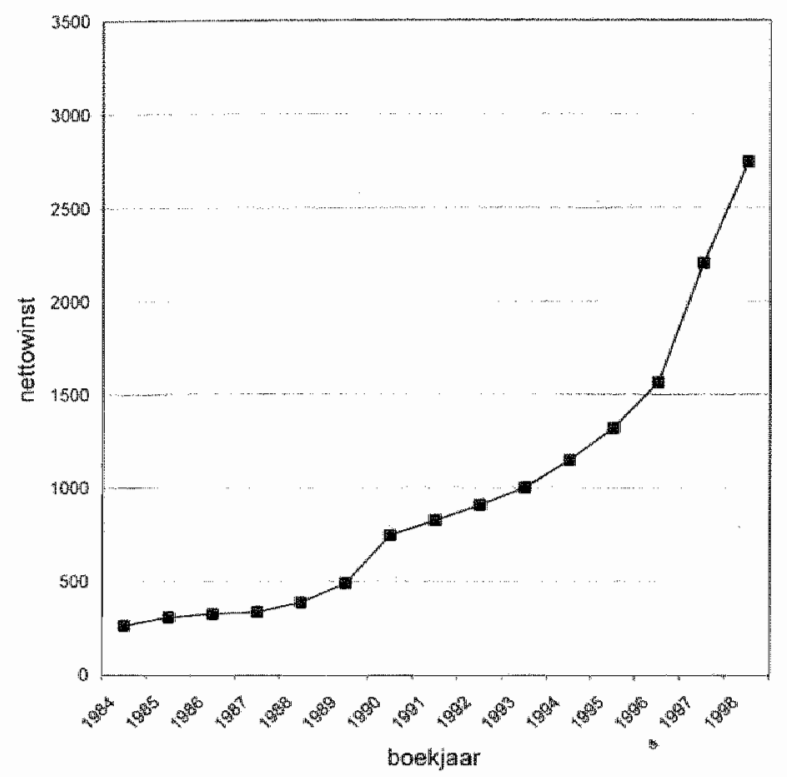

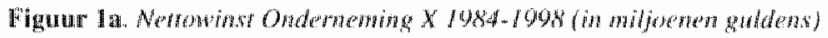

In figuur 16 ziet $u$ over dezelfde periode het verloop van de nettowimst van Onderneming $Y$. Hier ziet u dat de nettowinst van Onderneming $Y$ in de periode 1984-1998 enigszins fluctueert en niet trendmatig groeit zoals bij Onderneming $\mathrm{X}$. 


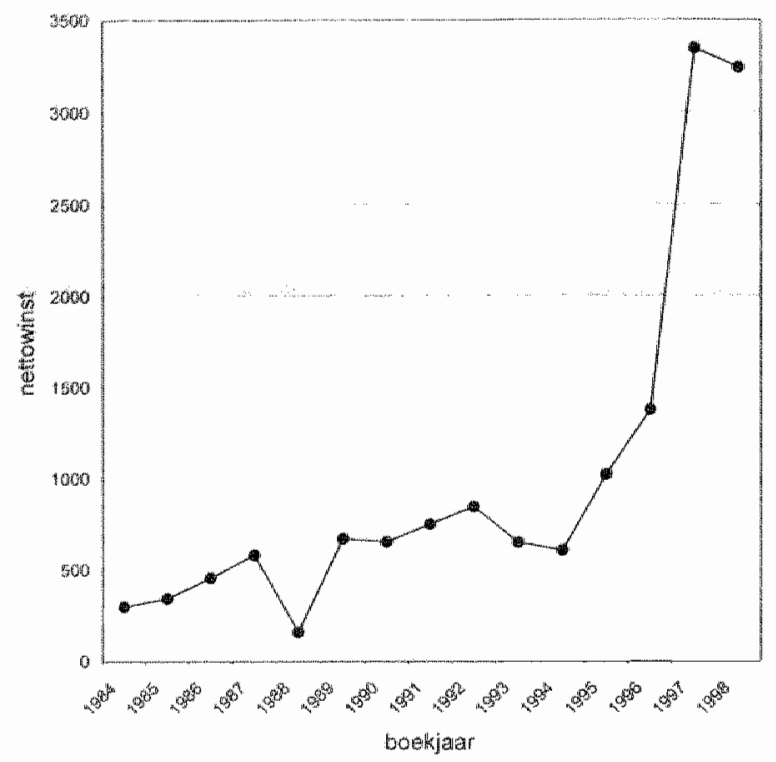

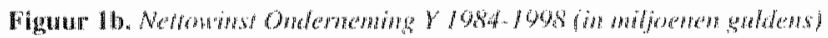

Gegeven is verder dat beide ondememingen in dezelde bedrijfstak operenen, even groot zijn en ook overigens met elkar vergelijkbaar zijn.

Stel nu dat $u$ van mij een bedrag van 61.000 krijgt met het verzoek dat bedrag te beleggen in de adandelen van Ondememing $X$ of van Onderneming $Y$. Wat zou dan uw keuze zijn? Belegt u die 61.000 dan volledig in aandelen van Onderneming $X$ of in andelen van Onderneming $Y$ ?

Heeft u uw keuze al gemaakt? ... 


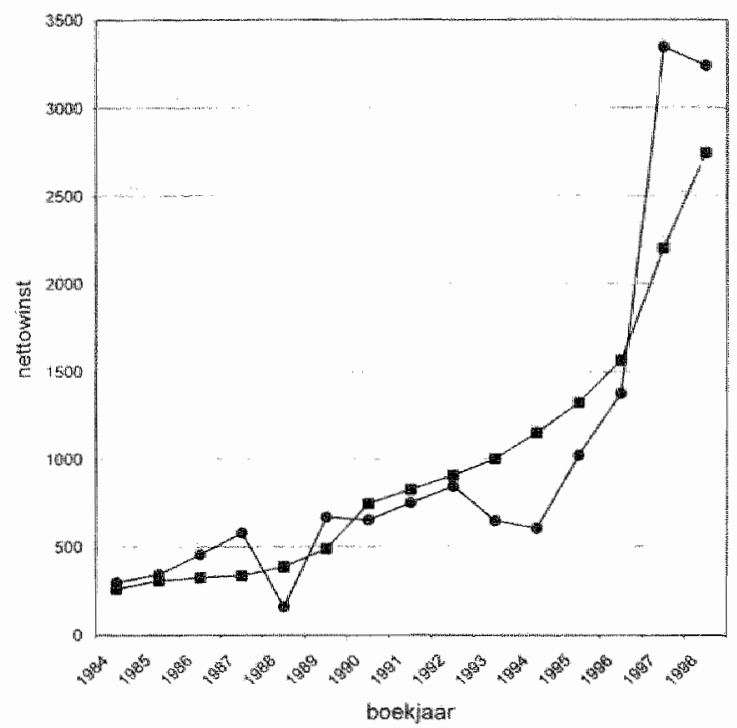

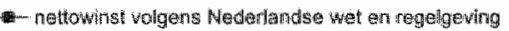

Figum 2. Netrowins AEOON $1984-1098$ im milloenen galdens

$U$ heeft allen gelijk!

Het makt namelijk niet wit in welke aandelen u die $€ I .000$ steekt. In werkelijkheid gaat het namelijk om eén en dezelfde onderneming. In figuur 2 is te zien dat het in beide gevallen de winstijfers van verzekeringsmaatschappij AEGON betreft. In het ene geval (Onderneming $X$ ) zijn de winstcijfers berekend in overeenstemming met Nederlandse versluggevingsregels. In het andere geval (Ondememing Y) zijn de winstcijters berekend volgens de Amerikatuse verslaggevingsregels. Omdat de aandelen van $A B G O N$ ook zijn genoteerd aan de New York Stock Exchange, moet AEGON in de Verenigde Staten cijfers presenteren die zijn gebaseerd op de zogenaamde United States Generally Accepted Accounting Principles (US GAAP). Die wijken op een groot antal punten af van de verslaggevingsregels dic in Nederland gelden.

U kunt zich voorstellen dat dit soort verschillen verwarrend en tot op zekere hoogte niet te begrijpen is voor de gemiddelde belegger. Niet alleen wanneer 
het gaat om één bepaalde ondememing die op verschillende kapitaalmarkten van elkaar af wijkende winstcijfers publiceert, maar ook wanneer Onderneming $X$ een Nederlandse en Onderneming $Y$ een Amerikaanse verzekeringsmaatschappij zou zijn.

De grondslagen die ondememingen hanteren voor de watdering en resultatbepaling worden voor een belangrijk deel bepaald door de regelgeving van het land waarin de onderneming is gevestigd. Dit betekent dat de financiele positie en behalde resultaten van ondememingen uit verschillende landen vaak moeilijk met elkaar kunnen worden vergeleken. Door de woortgaande interna tionalisering van het bedrijfsleven en de globalisering van de kapitaalmarkten is de behoefte aan het vergelijken van ondernemingen over de grenzen heen echter sterk toegenomen. Het hanteren van uiteenlopende waarderings- en resultatbepalingsgrondslagen kan een belangrijke barrière vormen om te komen tot goede beleggingsbeslissingen en daardoor de efficiëntie van de kapitaalmarkten nadelig beinvloeden. De roep om verslaggevingsregels die wereldwijd toepassing vinden is dan ook groot.

Doon het International Accounting Standards Committee (IASC) wordi al geruime tijd gewerkt aan harmonisering van verslaggevingsregels die in diverse landen gelden. Daartoe geeft zij International Accounting Standards (IASs) uit. De werkzaamheden van het LASC zullen naar alle waarschijnlijkheid in december 1999 resulteren in de afronding van een set van kemstandaarden warin de belangrijkste verslaggevingskwesties worden behandeld. $\mathrm{Zij}$ zouden de basis moeten wormen voor een wereldwijde harmonisering.

De vraag is nu - en dan kom ik tot het thema van mijn inaugurele rede - of de set van kernstandaarden de wereldtwal is waarnaar we op zoek zijn, een "Esperanto voor de externe financiele berichtgeving", of dat die juist leidt tot een Babylonische spraakverwarring. U moet van mij evenwel geen eenduidig antwoord op deze vraag verwachten. Ik zal wel bespreken langs welke lijnen wij kunnen komen tot een goed werkend "Esperanto voor de externe financiêle berichtgeving" en hoe we kunnen voorkomen dat een en ander ontaardi in een Babylonische spraakverwarring. Bij woorbaat is in ieder geval éen ding duidelijk: het IASC en de daarbij betrokken landen, organisaties en individuen hebben nog een lange weg te gaan.

In het vervolg van mijn inaugurele rede zal ik achtereenvolgens ingaan op de verslaggevingssystemen die er op dit moment internationaal kunnen worden 
onderscheiden, de effecten die verschillen in verslaggevingsregels kumnen hebben op de door ondememingen gepresenteerde winst- en vermogenscijfers en het belang om te komen tot een wereldwijde harmonisatic van regelgeving op het gebied van de jaarverslaggeving. Daana zal ik de belangrijkste obstaKels op de weg naar een wereldstandaard voor de externe financiele berichtgeving en de gewenste oplossingsrichtingen de revue laten passeren. Daarbij zal ik ingaan op de totstandkoming, de implementatie en de controle op de naleving van de IASs.

\section{Internationale verschillen in versllaggevingssystemen}

In het verleden is door velen getracht de internationale verschillen in verslaggevingssystemen in kaart te brengen door middel van classificatieschema ' $s$. In deze classificatieschema's worden landen in groepen ingedeeld op grond van bepaalde kenmerken.

Bekend en vaak aangehaald is de in figuur 3 weergegeven classificatie van Nobes (1983). Deze classificatie betreft de financiële jaarverslaggeving door beursgenoteerde ondernemingen in landen van de westerse wereld. Het jaat waarop de classificatie betrekking heeft is 1980 , dat wil zeggen voór implementatie van de Vierde EEG-richtlijn, gericht op de harmonisatie van het jaarrekeningenrecht, in de nationale wetten van de landen van cle Europese Unie. Bijzonder aan de classificatie van Nobes is dat hij een hierrarchie in de classificatie heeft aangebracht, hetgeen inzicht geeft in de mate waarin de verslaggevingssystemen van elkaar verschillen. Nobes onderscheidt daartoe classes. subclasses en families. De landen worden ingedeeld in twee hoofdcategonieën (classes), namelijk micro-based en macro-amiform.

In landen behorende tot de categorie micro-based stan bedrijfseconomische uitgangspunten centraal en de betekenis van een bepaalde onderneming woor de belanghebbenden van die onderneming, zoals aandeethouders en kredietwerschaffers. Landen die worden geclassificeerd als micro-based zijn $\mathrm{Neder}$ land, Australië, Nieuw-Zeeland, het Verenigd Koninkrijk, lerland Canada en de Verenigde Staten. Overigens, zoals we zien, neemt Nederland in het schema wan Nobes een enigszins geisoleerde positie in. In tegenstelling tol de Angelsaksische landen zijn de te kiezen verslaggewingsgrondslagen in Nederland

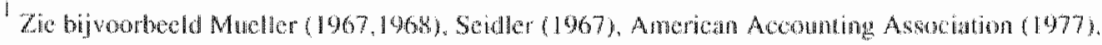
Da Costa, Bourgeois \& Lawson (1978). Fank (1979). Nair \& Frank (1989). Cray (1988) an Dothmik \& Salter (1995). 
niet strikt voorgeschreven, maar wordt bij de keuze een belangrijke rol toebedeeld aan de bedrijfseconomische theorie.

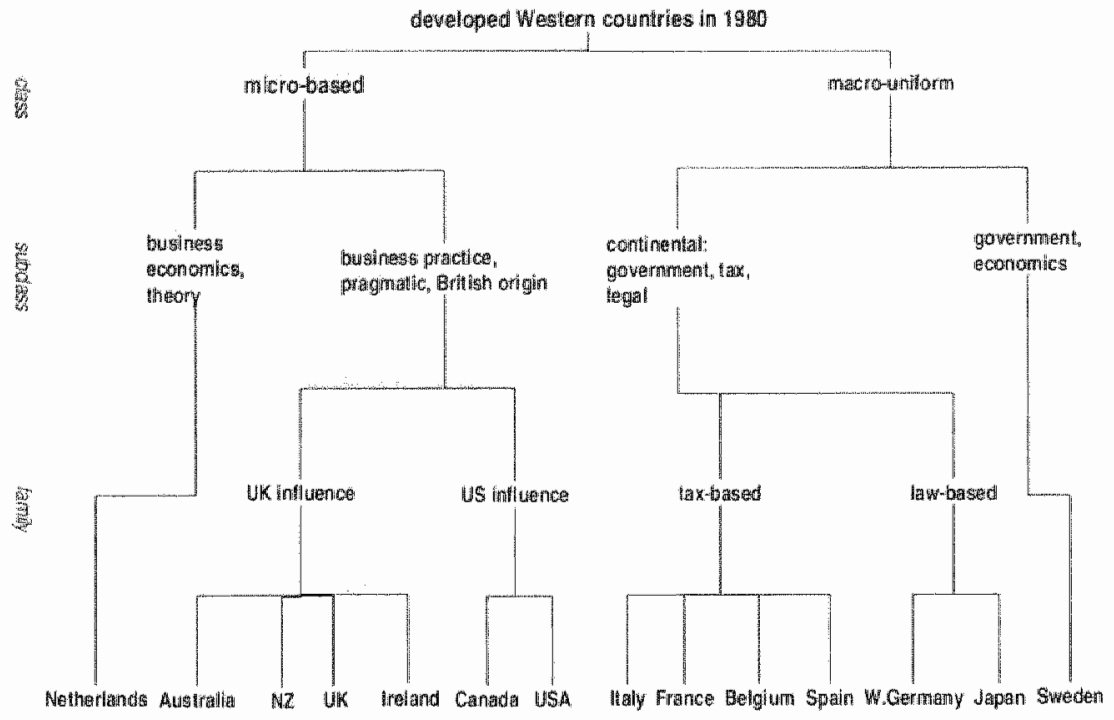

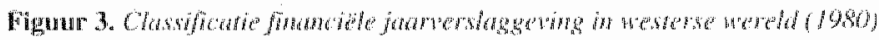

In landen behorende tot de categorie macro-uniform staan macro-economische uitgangspunten centraal en ligt de nadruk meer op de betekenis van een bepaalde onderneming voor de nationale economie. Hierbij speelt de belastingwetgeving cen belangrijke rol. In sommige landen worden financiële gegevens van ondenemingen opgeslagen in centrale gegevensbestanden op basis waarwan nationale statistieken worden opgesteld die dienen ter onderbouwing van de nationale economische politiek. Dit gebruik vereist een sterke mate van uniformening van de aan te leveren gegevens. Landen die worden gerekend tot de calegorie maromiform zijn Italie, Frankrijk, Belgie. Spanje, Duitsland. Japan en Zweden. 


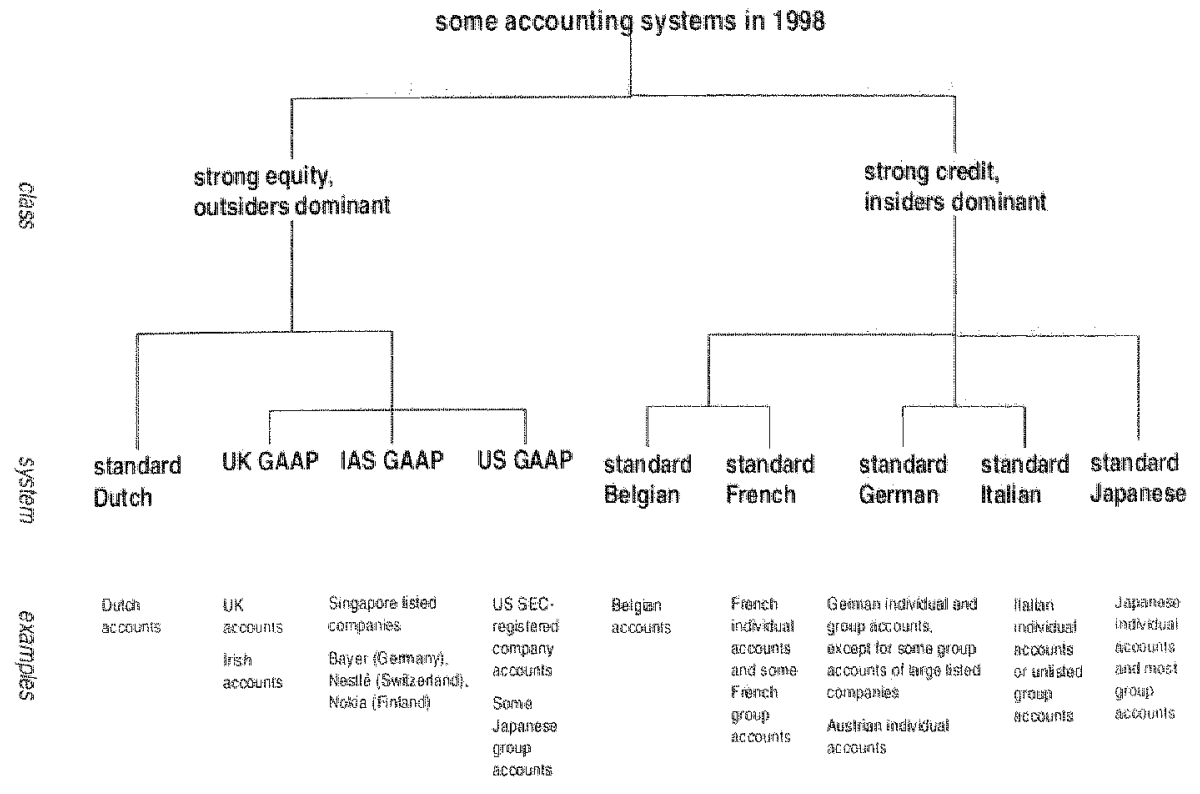

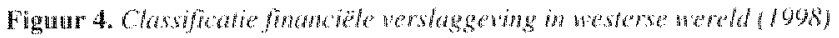

In een latere publicatie heeft Nobes zijn classificatie verfijnd en aangepast aan de ontwikkelingen die sinds 1980 hebben plaatsgevonden (Nobes, 1998). Figuur 4 geeft de classificatic van de verschillende verslaggevingssystemen in 1998 weer. In tegenstelling tot zijn schema met betrekking vot de situatic in 1980, mondt deze classificatie niet uit in een verdeling van landen over diverse caltegorieën.

In zijn nieuwste schema geef Nobes bij ieder onderscheiden verslaggevingssysteem een of meer voorbeelden van hun toepassing en wordt een bepaald land niet meer "toegewezen" aan een bepaald verslaggevingssystcom. US GAAP - de Amerikanse verslaggevingstegels - bijwonbeeld, worden roegepast in de jaarrekening van ondernemingen met en beursnotering in de Verenigde Staten, in figur 4 US SEC-registered crmpony accounts genoemd. Daaronder zijn ook de jaarrekeningen wan niet-Amerikaanse ondememingen met een beursnotering in de Verenigde Staten begrepen. Sfandard Gernan ... de Duitse verslaggevingsregels - wordt niet toegepast in de groepsaarrekening van sommige grote beursgenoteerde Duitse ondememingen. Zij passen in plaats daarvan de US GAAP of de standarden wan het IASC toe. Opvallend is 
bovendien dat naast de verslaggevingssystemen die hun oorsprong vinden in een bepaalde jurisdictie ook de standaanden van het $I A S C$ - aangeduid met $I A S$ GAAP - een plaats in het nieuwste schema is toebedeeld.

Doondat landen niet meer worden gekoppeld an cen bepaald verslaggevingssysteem en de standaarden van het IASC in het schema een plaats hebben gekregen. wordt de internationalisatic die zich in de afgelopen twee decennia op het gebied wan de externe financiele jaarverslaggeving reeds heeft voltrokken duidelyjk tot uitdrukking gebracht.

In het artikel warin Nobes zijn nieuwste schema presenteert, bespreekt hij dat veruit de belangrijkste verklaring van de internationale verschillen in verslag. gevingssystemen samenhangt met de verschillen in doelen die aan de financicle verslaggeving ten grondslag liggen. De verschillende doelen zijn terug te woeren op de wijze waarop ondernemingen worden gefinancierd en de daarmee gepaard gaande eigendoms- en zeggenschapsstructuren. Nobes maak: daarbij een onderscheid tussen strong equify/outsiders dominam en strong creditivsiders dominant.

In landen met verslaggevingssystemen behorende tot de categorie strong equity/ousiders dominant is er een sterke kapitalmarkt, worden ondernemingen voor een groot deel gefinancierd met eigen vermogen en is er sprake van een wijdverspreid aandelenbezit. De financièle verslaggeving is dan ook met name gericht op het verstrekken van relevante informatie ten behoeve van de oordeelsvorming en de daarop gebaseerde besluitvorming door de verschaffers van eigen vermogen, i.c. de aandeelhouders. De behoefte aan exteme financiele informatieverschaffing is groot ondat de andeelhouders doorgans niet direct zullen zijn betrokken bij de leiding van de onderneming en zij daardoor geen toegang hebben tot het interne management informatiesysteem. Bovendien wordt het in die omstandigheid van groot belang geacht dat de financiële informatic wordt gecontroleerd door een externe accountant alvorens die door de onderneming naar buiten wordt gebracht.

In landen met verslaggevingssystemen behorende tot de categone strong creditimiders dominant spelen de banken als kredietverschafters een belangrijke rol. In deze landen zijn er bovendien veel familiebedrijven en zijn de aandelen van beursgenoteerde ondernemingen voor een groot deel in handen van de banken of de overheid. In de financièle verslaggeving staat de bescherming van de kredietverschaffers centraal, aangezien de ondememingen met name worden gefunancierd met vreemd vermogen. Zij zijn er over het algemeen bij gebaat dat de uitkeerbare winst op een conserwatieve wijze word berekend, 
hetgeen invloed heeft op de verslaggevingsgrondslagen die bij de berekening worden toegepast. Belangrijke kredietverschaffers kunnen op bilaterale basis aan de kredietverlening eisen verbinden ten aanzien wan de financiele informatieverschaffing en daardoor gemakkelijker beschikken over informatie opgenomen in het interne management informatiesysteem. Om die reden zal er geen grote behoefte bestaan aan exteme fimanciële informatie die door een externe accountant is gecontroleerd.

In de verslaggevingsliteratuur worden naast de tweedeling strong equity outsiders dommant enerzijds en sirong credivinsiders dominant anderzijds, tal wan andere mogelijke verklaringen voor de internationale verschillen in verslaggevingssystemen gegeven. ${ }^{2}$ Deze kunnen echter vrijwel allemaal worden herleid tot genoemde tweedeling. Dit geldt bijwoorbeeld voor de invloed van belastingvoorschriften op de verslaggevingsregels en de invloed van het niveru en de omvang van het accountantsberoep op de kwaliteit van de jaarverslaggeving. Dat verslaggevingsregels al dan niet sterk worden beinvloed c.q. worden bepaald door belastingvoorschriften en dat de kwaliteit van de jaarverslaggeving samenhangt met het niveau en de omvang van het accountantsberoep, zijn niet zozeer oorzaken maar eerder gevolgen van verschillen in verslaggevingssystemen.

In landen met sterke kapitalalmarkten en een wijdverspreid aandelenbezit is er immers behoefte aan relevante en betrouwbare financiële informatic omtrent het reilen en zeilen van ondernemingen. Dit vraagt om verslaggevingsregels die niet zijn gekoppeld aan belastingvoorschriften, hetgeen betekent dat in deze landen twee regelgevingen naast elkaar zullen bestaan. Bovendien wordt het in landen met sterk ontwikkelde kapitaalmarkten van belang geacht dat de gepubliceerde financiële informatie is gecertificeerd door een externe accountant. Hierdoor heeft het accountantsberoep zich in deze landen goed kunnen ontwikkelen en is de omvang van het accountantsberoep relatief groot.

\section{Internationale verschillen in verslaggevingsregels en de invloed op winst- en vermogenscijfers}

De hatste jaren verschijnen tal van geschriften waarin de verschillen tussen wee of meer regelgevingen worden geanalyseerd, met name de analyses van verschillen tussen de eigen - lokale - verslaggevingregels en die van de Vere-

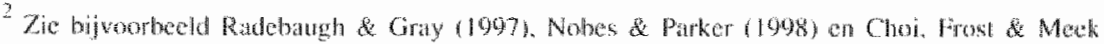
$11990 \%$
} 
nigde Staten of het IASC zijn zeer popular: Zonder al te veel op de technische details in te gaan, hebben deze verschillen onder meer betrekking op:

- de verwerkingswijze van bij acguisities betadde goodwill word die buiten de winst- en verliesrekening om in éen keer ten laste van het eigen vermogen gebracht of wordt het goodwillbedrag geactiveerd en uitgesmeerd over de economische levensduur ten laste van de winst- en verliesrekening gebrach?

- de waardering van immateriele vaste activa: word systematisch afgeschreven gedurende de economische levensduur die eindig wordt verondersteld of wordt uitgegaan van een oneindige economische levensduur en vindt afschrijuing alleen plats in het onverhoopte geval dat de indirecte opbrengstwarde daalt beneden de boekwaarde?

- de waardering van materielle vaste activa: wordt gewaardeerd tegen historische kosten of tegen actucle warde?

- de bepaling van de pensioenvoorziening en de pensioenkosten: wordt bij de berekening uitgegaan van de huidige salarissen of wordt ook rekening gehouden met verwachte salarisontwikkelingen in de toekomst?

- de bepaling van de belastingvoorziening: worden alle verschillen tussen de bedrijfseconomische en fiscale jaarrekening in aammerking genomen (integrale allocatiemethode) of slechts de verschillen die binnen afzienbare tijd tot afwikkeling komen (partiële allocatiemethode)?

- de bepaling van reorganisatie- of herstructureringsvoorzieningen: wordt dit soort woorzieningen gevormd zodra de ondememingsleiding het besluit tot reorganisatie of herstructurering heeft genomen of pas wanneer zi de plannen daartoe wereldkundig heeft gemaakt?

- de verwerkingswijze van dividenden: wordt het op balansdatum nog te dechareren dividend opgenomen onder de kortlopende schulden of vindt verantwoording onder het eigen vermogen plaats tot het moment waarop het dividend dadwerkelijk betaalbaar wordt gesteld?

Dit soort verschillen in warderings- en resultathepalingsgrondslagen kan de ciffers dic worden opgenomen in de jaarrekening van ondernemingen in be-

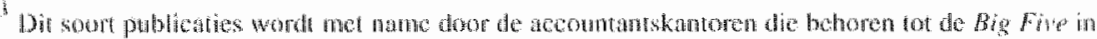

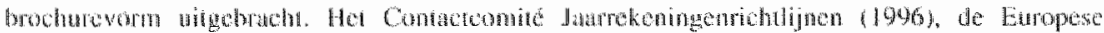

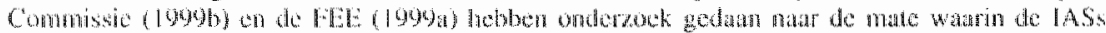

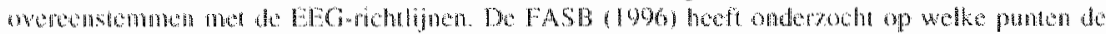

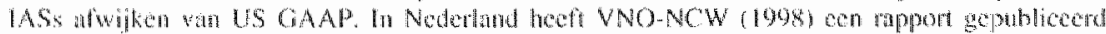

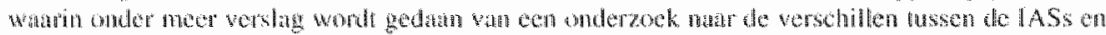
ide Noderlandse we - en regrolgong
} 
langrijke mate beinvloeden. Zojuist heeft u daarvan al een voorbeeld gezien toen ik de winstcijters van AEGON berekend volgens Nedertandse en Amerikaanse verslaggevingsregels met elkaar vergeleek.

In tabel I heb ik nog een paar - in mijn ogen - aansprekende voorbeelden opgenomen. Daarbij maak ik wederom gebruik van de cijfers van nietAmerikaanse ondemeningen met een beursnotering in de Verenigde Staten. Jaarlijks moeten deze ondernemingen bij de Securities and Exchange Commission (SEC) - de Amerikaanse beurstoezichthouder - een jaartapport deponeren dat is ingericht volgens het zogenaamde form $20-\mathbb{F}$. De daarin op te nemen jaarrekening dient in beginsel te voldoen aan US GAAP. Het is echter ook mogelijk om de jaarrekening op te stellen conform de verslaggevingsregels die gelden in het moederland van de onderneming. In dat geval moeten de verschillen tussen de verslaggevingsregels van het moederland en de US GAAP met een belangrijke invloed op het nettoresultaat on het eigen vermogen worden gekwantificeerd door middel van aansluitingsoverzichten freconciliation statements). De meeste niet-Amerikaanse ondernemingen hebben ervoot gekozen van deze faciliteit gebruik te maken, hetgeen betekent dat zij in hun Form 20-F tevens aansluitingsoverzichten moeten opnemen. De cijfers in tabel $\|$ zijn ontleend aan die aansluitingsoverzichten.

Tabel 1. Imloed van verschillen in warderings en resultaabepalingsgrondslagen op gepresenteerde cijfers (bedragen in miljoenen)

\begin{tabular}{|c|c|c|c|c|c|c|}
\hline $\begin{array}{l}\text { Natam } \\
\text { ondeneming }\end{array}$ & $\begin{array}{l}\text { Post in } \\
\text { jakrrekening }\end{array}$ & Jaar & Valuta & $\begin{array}{l}\text { Grondslagen } \\
\text { moederlatd }\end{array}$ & $\begin{array}{l}\text { US } \\
\text { GAAP }\end{array}$ & $\begin{array}{l}\text { Invoud } \\
\text { an } \%\end{array}$ \\
\hline \multirow[t]{4}{*}{ Daimler-Benz } & nettoresultaat & 1993 & $\mathrm{DM}$ & 615 & -1.839 & -399 \\
\hline & nettoresultat & 1994 & DM & 895 & 1.052 & +18 \\
\hline & nettoresultad & 1995 & DM & -5.734 & -5.729 & 0 \\
\hline & eigen vernogen & 1995 & DM & 13.842 & 22.860 & +65 \\
\hline \multirow[t]{2}{*}{ Britich Airways } & nettorexultaat & 1994 & $E$ & 274 & 14.5 & -47 \\
\hline & nettoresultast & 1995 & $e^{2}$ & 250 & 297 & 40 \\
\hline News Corporation & aigen vermogen & 1995 & $A$ & 16.582 & 9020 & 46 \\
\hline Unilever & eigen vermogen & 1995 & $f$ & 13.989 & 27.402 & $\$ 96$ \\
\hline $\mathrm{NG}$ & mettoresultat & 1997 & $f$ & 4.105 & 5.393 & +31 \\
\hline ABNAMRO & nettoresultat & 1997 & $f$ & 3.853 & 3.470 & -10 \\
\hline \multirow[t]{2}{*}{ Volvo } & nettoresultat & 1997 & SEK & 10.359 & 6.556 & -37 \\
\hline & netioresuluat & 1998 & SEK & 8638 & 9.432 & +9 \\
\hline
\end{tabular}


In 1993 werkreeg Daimler-Benz als cerste Duitse ondememing cen aandelennotering aan de New York Stock Exchange. In tabel 1 kan worden afgelezen dat Daimler-Benz in dat jaar volgens Duitse grondslagen een winst van rum DM 600 miljoen heeft behaald, terwijl toepassing wan US GAAP leidt tot een verlies van maar liefst DM 1,8 miljard. In het daaropvolgende jaar is er in beide gevallen sprake van een positief resultaat. Ditmaal is het resuitaat volgens US GAAP echter hoger dan het resultaat volgens Duitse grondslagen. In 1995 is er nawwelijks verschil tussen het resultaat volgens US GAAP en dat volgens Duitse grondslagen. Het eigen vermogen aan het einde van dat jaar daarentegen is volgens US GAAP $65 \%$ hoger dan volgens Duitse grondslagen. Bij British Airways zien we in 1994 een winstcijfer dat volgens US GAAP lager is dan volgens Britse grondslagen. In 1995 is het ongekeerde het geval. Het ultimo 1995 door het Australische News Corporation gepresenteerde eigen vermogen wordt door toepassing van US GAAP bijna gehalveerd. Bij het Nederlands/Britse Unilever is er daarentegen sprake van een verdubbeling van het gepresenteerde eigen vermogen. In 1997 is de winst van ING volgens US GAAP hoger (ruim 30\%) en van branchegenoot ABN AMRO juist lager (10\%) vergeleken met de winst volgens Nederlandse grondslagen. Bij het Zweedse Volwo laat toepassing van US GAAP in 1997 een lagere en in 1998 een hogere winst zien vergeleken met de winstcijfers volgens Zweedse grondslagen. ${ }^{4}$

Wat we van deze woorbeelden kunnen leren is dat de toepassing van US GAAP door niet-Amerikaanse ondernemingen een grote invloed kan hebben op de door ondernemingen gepresenteerde cijfers. Opvallend is dat dit kennelijk ook geldt voor ondernemingen afkomstig uit landen die volgens het schema van Nobes op het gebied van de jaarverslaggeving een zekere verwantschap hebben met de Verenigde Staten (zie figuur 3).

Voorts moeten we bedenken dat ondernemingen met beursnoteringen in het buitenland doorgaans intenationaal georiënteerd zullen zijn en zij bij de keuze van de waarderings- en resultatbepalingsgrondslagen de intemationale ontwikkelingen met betrekking tot de jaarverslaggeving zullen betrekken. Uit een studic van Vergoossen (1996) gericht op de jaarverslaggeving van Nederlandse onder-

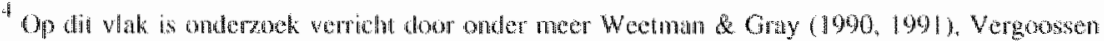

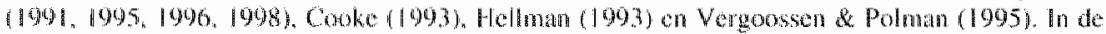

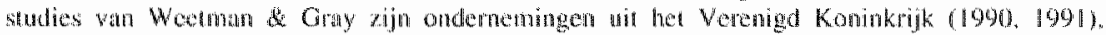
Zweden (1901) on Nederland (1991) betrokken. De studies van Vergoossen an Vergeossen \& Pulman hebben betreking op Nedeflandse ondememingen. De stude van Cooke benef Japanse

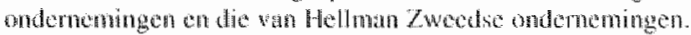


nemingen met een beursnotering in de Verenigde Staten; bijvoorbeeld, blijkt dat deze ondernemingen een jaarrekeningbeleid aan de dag leggen in de richting van het steeds meer toepassen van grondshagen die overeenstemmen met US GAAP maar dat desondanks de aansluitingsoverzichten in het Form $20-\mathrm{F}$ omvangrijke aanpassingen bevatten. Dit betekent dat bij (beursgenoteerde) ondernemingen die een dergelijke internationale onientatie niet hebben, de gekozen verslaggevingsgrondslagen nog meer van elkaar zullen afwijken.

Door het grote scala aan potentiële afwijkingen zal het bovendien niet goed mogelijk zijn om vuistregels te geven aan de hand waarvan jaarrekeningen van ondernemingen die zijn opgesteld op basis van verschillende sets van verslaggevingsregels met elkaar vergelijkbaar te maken.

Ten slotte wil ik erop wijzen dat de verschillen in verslaggevingsregels tussen landen niet alleen betrekking hebben op waarderings- en resultaatbepalingsgrondslagen, maar ook op de additionele informatieverschaffing in de toelichting op de balans en winst- en verliesrekening. De eisen die worden gesteld aan de additionele informatieverschaffing (disclosure) zijn in landen met een sterke kapilaalmarkt en een wijdverspreid aandelenbezit doorgaans veel omvangrijker, gedetailleerder en stringenter gefomuleerd dan in landen waarin banken of de overheid een overwegende rol als vermogensverschaffer spelen.

Binnen eerstgenoemdle categorie kunnen op het gebied van de additionelle informatieverschaffing overigens ook belangrijke verschillen bestaan. Dit komt onder meet naar voren in een studie van Vergoossen (1996), waaruit blijkt dat de jaarrekening in het Form 20-F van veel Nederlandse ondemeningen met een beursnotering in de Verenigde Staten meer toelichtingsinformatie bevat dan de in Nederland gepubliceerde jaarrekening van dezelfde ondernemingen. De informatie-elementen waar het om gaat hebben onder meer betrekking op pensioenen, belastingen, voorzieningen, schulden, operationele leaseverplichtingen en derivaten. Datarnast is de gesegmenteerde informatieverstrekking in het Form 20 -F valak uitgebreider. ${ }^{5}$

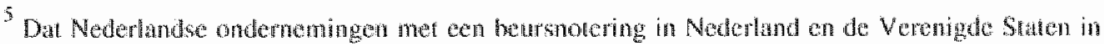

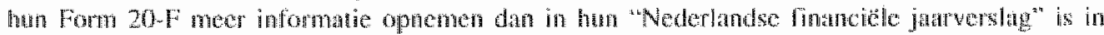

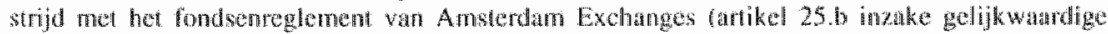
informatieverstrekking). De bevindingen wit het onderoek van Vergonssen waren woor Anster. dam Exchanges dan ook abreiding on de desbetreffende ondernemingen door middel van een

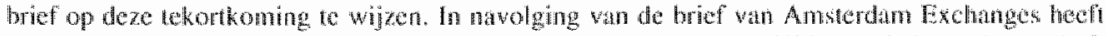

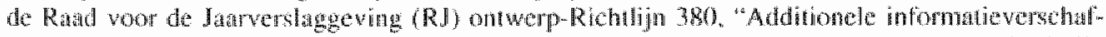

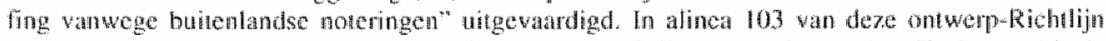

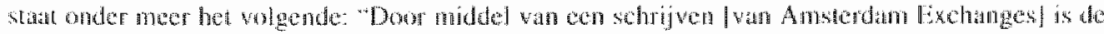




\section{Harmonisatie regelgeving omtrent financiele verslaggeving}

Het zal duidelijk zijn dat de zojuist beschreven toestand onwenselijk is in een wereld warin sprake is van een voortgaande internationalisering van het bedrijfsleven en darmes gepard gaande een sterke globalisering van de kapitaalmarkten. De behoefte aan regelgeving op het gebied van de financièle verslaggeving die wereldwijd toepassing vind, is dan ook de laatste jaren sterk toegenomen. De voordelen van een internationale harmonisatie van de externe financiële berichtgeving zijn groot voor zowel de opstellers, de gebruikers als de controlleurs.

De intemationalisering van het bedrifsteven houdt in dat de activiteiten van steeds meer ondernemingen woor een groot deel in het buitenland plaatsvinden, onder meer door grensoverschrijdende fusies en acquisities. Dit betekent dat deze ondernemingen worden geconfronteend met de verslaggevingrregels die gelden in de landen warin dochtermatschappijen of deenemingen zijn gevestigd. Indien die verslaggevingsregels van elkaar afwijken, compliceent dit het consolidatieproces dat moet uitmonden in een groepsjaarrekening voor externe doeleinden. Ook word het opstellen van financiele overzichten voor interne doeleinden bemoelijkt, bijvoorbeeld on te beoordelen hoe de prestaties van dochtermaatschappijen die in verschillende landen opereren zich tor clkaar verhouden. De voordelen van een internationale hamonisatie van verslaggevingsregels voor multinationale ondernemingen zijn dan ook evident.

In verband met de internationalisering van hun activiteiten doen ondernemingen steeds vaker een beroep op buitenlandse kapitaalmarkten, hetgeen onder meer betekent dat zij aan de verslaggevingseisen van de desbetreffende beurzen moeten voldoen. Ook hier kan intemationale harmonisatie tot belangrijke

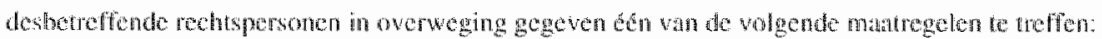

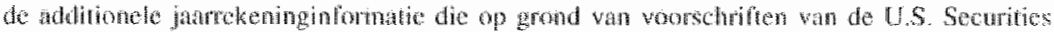

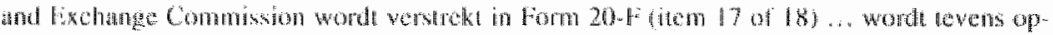

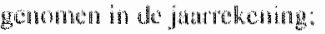

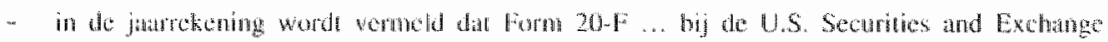

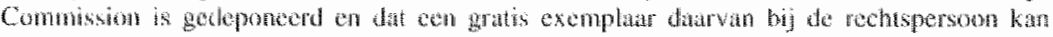
wordch wpgevratatal."

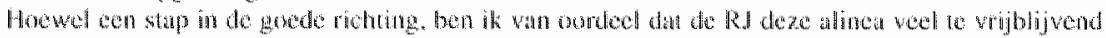

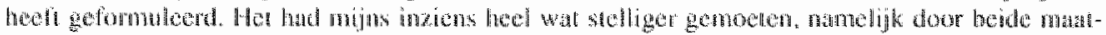

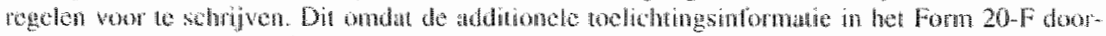

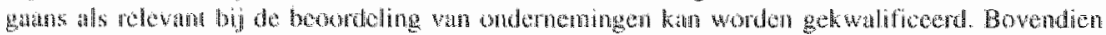

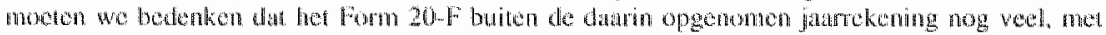

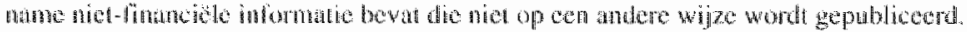


kostenbesparingen voor het bedrijfsleven leiden doondat voor beursnoteringen in het buitenland geen afzonderlijke financiele jaarstukken meer behoeven te worden opgesteld.

Niet alleen de vraag naar, maar ook het aanbod wan kapitaal globatiseen, dat wil zeggen ook beleggers - institutioneel en particulier - begeven zich op buitenlandse beurzen. Bovendien zijn beleggingsstrategieèn tegewwootig meer gericht op het beleggen in bepaalde bedrijftakken in plaats van in bepaalde geografische gebieden of landen. De behoette bij beleggers en beleggingsanalisten on de cijfers van ondernemingen mel elkaar te vergelijken over de grenzen heen is dan ook toegenomen. Het zal duidelijk zin dat internatio nale hamonisatie van de regelgeving omtrent financiele verslaggeving die leidt tot een verbetering van de vergelijkbaarheid wan ondememingen de inter nationale beleggingsanalyse in belangrijke mate kan faciliteren. Intemationale hamonisatie voorkomt ook dat internationaal georiènteerde beleggers in vor warring worden gebracht. Beursnoteringen in het buttenland leiden er immers niet meer toe dat afzonderlijke financiële jaarstukken met mogelijk sterk nfwijkende cijfers moeten worden opgesteld.

Behalve woor de ondernemingen als opstellers en de beleggers en beleggingsanalisten als belangriikste gebruikers van de externe financiele berichtgeving, zijn er voor controleurs - met name de intemationaal opererende accountantskantoren - eveneens belangrijke voordelen verbonden aan het proces van intemationale hamonisatie. Zo kan de controle van het consolidatieproces en de controle op de naleving van de verslaggevingsregels worden vergemakkelijkt. Daarnaast wordt binnen de accountantskantoren de uitwisselbaarheid van het controlerende personeel vergroot.

Na bespreking van de voordelen verbonden aan een internationale harmonisatie van de externe financiële berichtgeving, wil ik kort aan de orde stellen waarop de harmonisatie-inspanningen zich primair zouden moeten richten. Daartoe onderscheid ik twee elementen, namelijk de soort van ondernemingen en de onderdelen van de financiẻle verslaggewing.

De harmonisatic-inspanningen moeten zich nijins inziens primair richten op de ondememingen die beursgenoteerd zijn. Hierdoor word ingespeeld op de ontwikkeling dat niet alleen de ondenemingen mat ook de beleggers zich steeds vaker op buitenlandse kapitaalmarkten begeven. Daartoe is het vam belang dat de cijfers van alle beursgenoteerde ondememingen - vooral binnen een bepaalde bedriffstak - met elkaar kunnen worden vergeleken. Dat de cijfers van beursgenoteerde en niet-beursgenoteerde ondernemingen in een be- 
pald land niet (mexr) vergelijkbatar zijn lijkt mij niet bezwaarlijk, aangezien de kring van belanghebbenden verschillend is. Beperking van de harmonisatie van de financiêle verslaggeving tot de ondernemingen met een beursnotering in meerdere landen (cross-border listings), zou ertoe leiden dat de cijfers van deze ondernemingen niet wergelijkbaar zijn met de cijfers van soortgelijke ondernemingen die maar in één land een beursnotering hebben. Dil zou in onvoldoende mate recht doen aan de globalisering van het aanbod van kapitaal die zich op dit moment manifesteert. De hamonisatie-inspanmingen moeten zich niet primair richten op zowel de beursgenoteerde als niet-beursgenoteerde ondernemingen. Het lijkt mij weinig zinvol om - kosten wat het kost - emaar te streven dat de cijfers van bijvoorbeeld een beursgenoteerde bakkersfabriek kumnen worden vergeleken met de cijfers wan "de bakker op de hoek". Het aantal belanghebbende buitenstaanders is bij laatstgenoemde onderneming over het algemeen vrij beperkt en bovendien zal dit soont ondernemingen de externe financiele berichtgeving - voor zover vereist - zodanig willen inrichten dat zoveel mogelijk tevens wordt voldaan aan de belastingvoorschriften. Hierdoor wordt op de administratieve lasten bespaard.

De vrag is vervolgens of gestreefd moet worden naar een internationale harmonisatie van zowel de vennootschappelijke als de geconsolideerde jaarrekening of dat de harmonisatie-inspanningen zich uitsluitend moeten richten op de geconsolideerde jaarrekening. Dat laatste is naar mijn mening (vooralsnog) voldoende. Het is immers met name de geconsolideerde jaarrekening waarin informatie is opgenomen die van belang is voor de oordeelsvorming en besluitvorming van het beleggend publiek. Bovendien zal bet door het juridische karakter van de vennootschappelijke jaarrekening en de sterke verwevenheid die in sommige landen bestaat tussen verslaggevingsregels en fiscale voorschriften moeilijk zijn te komen tot een internationale harmonisatie van dit onderdeel van de financièle verslaggeving.

Sinds twee a drie decennia is er op het gebied van de regelgeving inzake de externe financiele berichtgeving een tweetal belangrijke hamonisatieprocessen aan de gang, namelijk die van de Europese Unie en die wan het IASC.

Het harmonisatieproces van de Europese Unie vierde vooral in de jaren tachlug hoogtij met de publicatie van de Vierde en Zevende EEG-richtlijn en de verwerking van deze richtlijnen in de nationale wetten van de lidstaten. De Vierde en Zevende EEG-richtlijn hebben betrekking op de vennootschappelijke jaarrekening en hot directieverslag respectievelijk de geconsolideerde jaarrekening. Daarnaast zijn twee specifieke richilinen omtrent de verslaggeving door 
financiele instellingen uitgegeven en in de mationale wetten van de lidstaten verwerkt. Dit alles heeft evenwel niet tot een strikte harmonisatie van de waarderings- en resultatbepalingsgrondslagen geleid, aangezien de BEGrichtijnen betrekkelijk veel ruimte laten bij de aanpassing van de nationale wetten. Deze rumte werd noodzakelijk geacht vanwege de grote diversiteit binnen Europa. De EEG-richtijnen blijken overigens te inflexibel om snet te kunnen inspelen op ontwikkelingen die zich op verslaggevingsgebied voordoen, bijwoorbeld ten aanzien van derivaten en immateriele productiemiddelen.

De jaren negentig staan in het teken van het streven van het IASC te komen tot een werregaande harmonisering of - beter gezegd - uniformering op mondial niveau van de regelgeving op het gebied van de externe financiele berichtgeving. Zoals uit het navolgende nog zal blijken is de steun en belangstelling voor het werk wan het IASC in die jaren enom toegenomen, met name ook binnen de Europese Unie als gevolg van de eigen harmonisatieperikelen. Hoewel het $I A S C$ een set van kernstandaarden vrijwel geheel heeft afgerond, zullen we zien dat aan het mondiale proces van uniformering nog heel wat haken en ogen zitten.

\section{International Accounting Standards Committee en het belang van zijn standaarden}

Hef $\amalg A S C$ is een onathankelijk privaatrechtelijk orgaan dat in 1973 is opgericht door accountantsorganisaties uit Australiè, Canada, Duitsland, Frankrijk, Japan, Mexico, Nederland, het Verenigd Koninkrijk \& Ierland en de Verenigde Staten. Sinds 1983 zijn alle leden van de International Federation of Accountants (IFAC) tevens lid van het IASC. Inmiddels hebben zich ongeveer 150 accountantsorganisaties uit meer dan 100 landen bij de IFAC aangesloten.

Het IASC heeft de volgende twee doelstellingen:

"(a) ro formulate and publish in the public interest accounting standards to be observed in the presentation of financial statements and to promote their worldwide acceptance and observance, and

(b) to work generally for the improvenen and harnonisafion of regulations, accounting standards and procedures relating to the presentation of $f i$. mancial statements. "(IASC, 1999)

Het IASC heeft inmiddels bijna veertig standaarden gepubliceerd. In tabel 2 ziet u daarvan een opsomming. 
Tabel 2. Overzich Internowonal Accouming Standards

$1 \mathrm{AS}$ Tiet

Latastste wijziging in

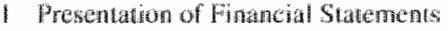

2 livenorics

3 ingerrokken en worwagen door IAS 27 en 28

4 Deprectition Accounting

5 ingetrokken on wervangen door $1 \mathrm{AS} 1$

6 ingetrokken en vervangen door IAS 15

7 Cats Flow Sétements

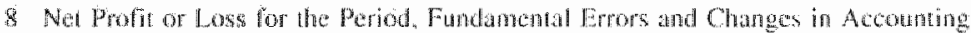

Policies

9 Reserath and Development Cosis.

10 Rvents Atw the Balance Shat Date

II Construction Contracts.

12 Hncome Tares

13 ingetrokken en vervangen toon LAS I

14. Segmen Reporing

15 Inlomation Refllecting the Efects of Changing Prices

16 Property. Pland and Equipment

17 Leases

18 Reverue

19 Employer Benafints

20 Accomting for Govenment Grants and Disclostre of Govemment Asswance 1994

21 The Ellects of Chuges in Foreign Fxchange Rates

22 Business Combinations 1998

23 Borrowing Coss 1993

24 Related Party Disclosures 1994

25 Accourthe for linvestments 1994

26 Accounting and Reporthe by Retirement Benofit Pluns 1994

27 Consoliduted Financial Sratements and Accounting for Invermonts in substiares 1901

28 Accounting for Investments in Associates

29) Financial Reporting in Hyprinflationaty Economies

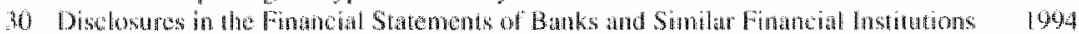

3 Finamial Reporing of Interests in Join Ventures 1969

32 Financist: Instruments: Diselesure ind Prosentation

33 faming per Shatre

3 Interim Finweisal Reponting 1908

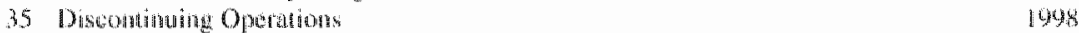

36 Impatinght of A sicts $\quad 1998$

37 Proverom, Contmgen Liabilitiss and Contigent Assers

38 intanuble Asuts 1908




Hoewel de standaarden die het $\mathrm{ASC}$ uitbrengt op zichzelf geen rechtskracht hebben, is - zoals gezegd - hun betekenis in het afgelopen decennium sterk toegenomen en dan niet alleen ondat steeds meer accountwntsorganisaties lid zijn van het IASC. Ook de drastische reductie in 1993 van het aantal opties in de IASs met betrekking tot de toe te passen wasterings- en resultaatbepalingsgrondslagen heef het aanzien van het LASC en zijn standaarden aanmerkeljk werhoogd. Dit was een uitwloeisel van het zogenaamde Comparability and lmprovenents-project.

Ik zou hier nog twee andere ontwikkelingen willen bespreken die een belang* rijke bijdrage (kunnen) leveren aan de statusverhoging van het IASC en zijn standaarden:

1. de overeenkomst van het IASC met de International Organization of Securities Conmissions (IOSCO) over een mogelijke erkenning van de IASs;"

2. de steun van de Europese Commissie aan de werkzamheden van het IASC:

In juli 1995 is het IASC met de IOSCO overeengekomen dat laatstgenoende tot erkenning wan de IASs zal overgaan, nadat bepaalde verslaggevingsproblemen adequat zijn opgelost en in LASs zijn vastgelegd. De overeenkomst heeft specifiek betrekking op de ondernemingen die niet alleen in hun eigen land maar ook in het buitenland emitteren of beursgenoteerd zijn (cross-border offerings and listings). De overeenkomst omvat dus niet alle beursgenoteerde ondernemingen.

De inspanningen van het IASC waren erop gericht orn in 1998 de overeengekomen set van kernstandaarden te presenteren. Op twee minder belangrijke onderwerpen na is dat ook gelukt. ${ }^{7}$ De IOSCO is dan ook dit jaar gestart met een beoordeling van de set van kernstandaarden. Uitsluitsel over het al dan niet erkennen van de IASs en de voorwaarden waaronder, is evenwel niet eerder dan in de loop wan volgend jaar te verwachten. De IOSCO streeft nar consensus, omdat zij de toepassing van de IASs niet kan afdwingen. Het is aan de

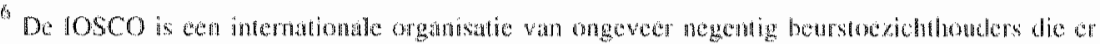

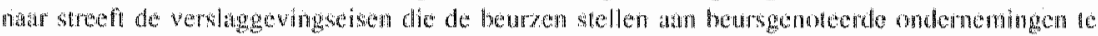

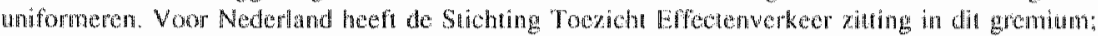
ront de Verenigde Staten is dat de $\$ \mathrm{SC}$.

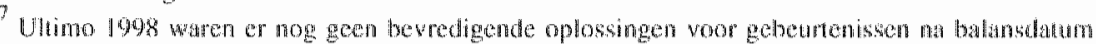

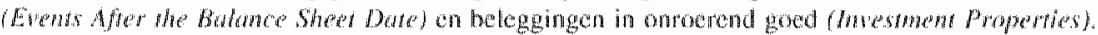

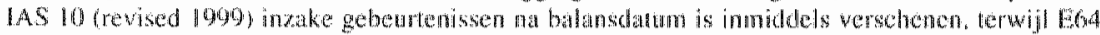

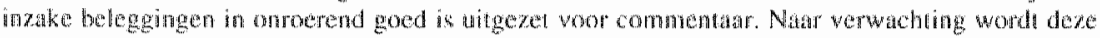

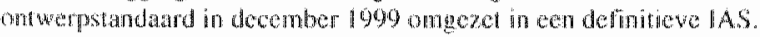


leden van de $\mathbb{}$ OSCO om die standaarden daadwerkelijk voor te schrijven. De uitkomst van dit proces van erkenning door de beurstoezichthouders is van groot belang voor de toekomst van het IASC als global standard-setter. Daarbif is het essentieel dat de Verenigde Staten als grootste kapitaalmarkt meedoet, matar de Amerikaanse beurstoezichthouder - de SEC - is zeer terughoudend. De SEC, die veet invloed heeft in de IOSCO, is uitshitend bereid de LASs te accepteren wanneer die in haar ogen allesomvatiend en van hoge kwaliteit zijn en strikt worden geinterpreteerd en toegepast. Bij de beoordeling zal overigens niet alleen de inhoud van de bestaande IASs een rol spelen, maar zullen ook de wijze waarop de standaarden in de toekomst torstandkomen c.q. worden onderhouden en de wijze waarop de standaarden in de praktijk worden geimplementeerd en de naleving wordt afgedwongen van doorslaggevende betekenis zijn (Leder, 1999, pag. 469-70). Op de kwesties totstandkoming, implementatie en naleving van de IASs zal ik zo meteen dieper ingaan.

De overeenkomst van het IASC met de IOSCO was een belangrijke reden voor de Europese Commissie om de werkzaamheden van het IASC expliciet te steunen en af te zien van de oprichting van een European Accounting Standards Board. Dit komt tot uitdrukking in de Mededeling die de Europese Commissie in november 1995 naar buiten bracht (Europese Commissie, 1995). Daarin staat onder meer te lezen dat het de bedoeling is dat geen nieuwe EEGjaarrekeningrichtlijnen meer worden voorgesteld en dat de Europese harmonisatie op het gebied van het jaarrekeningrecht zich zou moeten concentreren op de geconsolideerde jaarrekening en op de grotere, met name beursgenoteerde ondernemingen. De lidstaten zouden ondernemingen in staat kunnen stellen om de IASs toe te passen in de geconsolideerde jaamekening, voor zover die althans niet strijdig zijn met de EEG-richtlijnen. Bovendien zouden de lidstaten door middel wan het Contactcomité Jaarrekeningenrichtlijnen hun acciviteiten in thet IASC beter moeten gaan coördineren, zodat de invloed van de Europese Unie in dit internationale gremium toeneemt." De Europese Commissie, bij monde wan Van Hulle (1999, pag. 473-4), benadrukt overigens - net zoals de $10 S \mathrm{CO}$ - dat voor de ontwikkeling van internationale verslaggevingsstandaarden niet alteen de inhoud, maar ook de wijze van totstandkoming, een consistente toepassing en een effectieve controle op de naleving van de IASs van eminent belang zijn.

\footnotetext{
Het Contactemite Jatrokeningentichtijnen besprekt problemen in wetband met de topassing

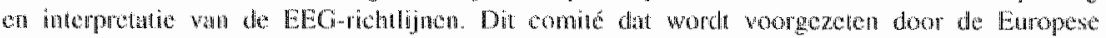

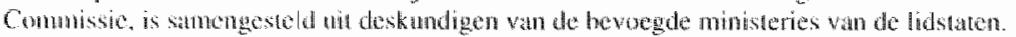


Sinds de publicatie van de Mededeling door de Europese Commissie hebben diverse lidstaten van de Europese Unie - waaronder Belgie, Duitsland, Frankrijk en Italie - wetgeving uitgevardigd de de rechtstreekse toepassing van "internationaal erkende verslaggevingsstandaarden" toestaat in de geconsolideerde jaarrekening van beursgenoteende ondernemingen. Daarbij geldt wel als eis dat niet mag worden afgeweken van de EEG-richtlijnen. ${ }^{9}$ Frankrijk stelt als additionele eis dat de "intemationaal erkende verslaggevingsstandaarden" vertaald zijn in het Frans. Onder "internationaal erkende verslaggevingsstandaarden" worden overigens niet alleen de IASs, maar ook de US GAAP verstaan. Hierdoor zouden de ondernemingen in genoemde landen die tevens een beursnotering in de Verenigde Staten hebben, in beginsel kunnen volstatan met een geconsolideerde jaarrekening die is opgesteld in overeenstemming met de US GAAP. Franse ondernemingen hebben dit voordeel niet, omdat de US GAAP (nog) niet in het Frans zijn vertaald. De IASs zijn well in het Frans beschikbaar.

\section{Obstakells op weg naar wereldstandaard}

Het lijkt erop dat de komende jaren cruciaal zijn voor het IASC. Wil het IASC in de toekomst de rol van global standard-setter vervullen dan zullen de volgende zaken naar behoren moeten worden geregeld:

- de wijze waarop de IASs totstandkomen c.q. worden onderhouden;

- de wijze waarop de implementatie plaatsvindt en een consistente interpretatie en toepassing van de IASs is gewaarborgd;

- de wijze waarop de nalleving van de IASs wordt afgedwongern.

In figuur 5 heb ik in de vorm van de façade van een Griekse tempel gevisualisecrd hoe deze drie zaken zich tot elkatr verhouden.

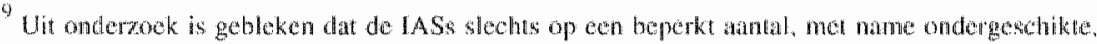

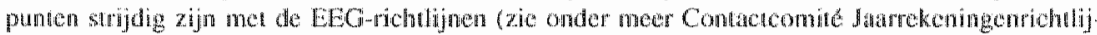

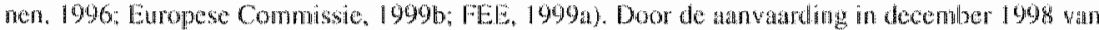

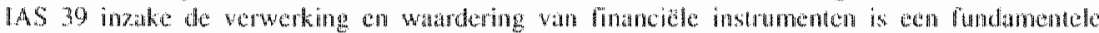

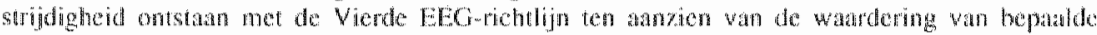

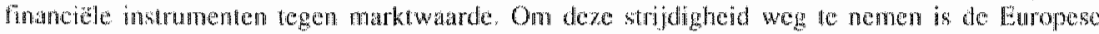
Commissie wan plan de Viatede EEG-richtijn atan te pawsen.
} 


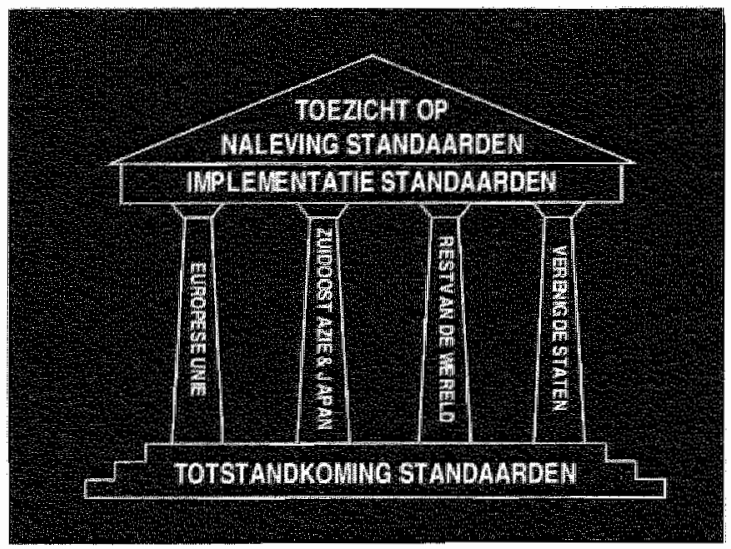

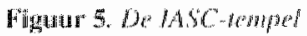

Het fundament van de tempel is het institutionele ramwerk waarbinnen de IASs totstandkomen. Dit raamwerk moet aanvaardbaar zijn voor alle betrokken partijen. Is dal niet het geval dan is er geen draagvlak en zijn vraagstukken met betrekking tot de implementatie en de wijze warop de naleving van de IASs wordt afgedwongen niet eens aan de orde. Zonder fundament stort het bouwwerk in elkaar. Landen of jurisdicties zullen niet bereid zijn de IASs te implementeren in hun eigen regelgeving.

Implementatie van de IASs is een noodzakelijke voorwarde voor het opzetten van een mechanisme waarmee de naleving kan worden afgedwongen. Zolang de IASs niet zijn voorgeschreven of op een andere manier zijn geimplementeerd in de nationale regelgeving, hoeven ze niet te worden nageleefd. Het spreekt vanzelf dat er dan wan het afdwingen van de naleving van de IASs geen sprake kan zijn.

De vier zuilen van de tempel worden gevormd door landen of regio" $\$$ : de Europese Unie, de Verenigde Staten, Zuidoost Azie \& Japan en de rest van de wereld. Het zal duidelijk zijn dat als eén van de buitenste zuilen - de Europese Unie of de Verenigde Staten - wegvalt, het bouwwerk erg instabiel zal worden en er eigentijk niet meer van het IASC als global standard-sefter kan worden gesproken. De middelste zuilen - Zuidoost Azie \& Japan en de rest van de wereld - zijn volgens mij niet doorslaggevend om het bouwwerk overeind te houden. Om tot een wereldstandaard te komen zijn de steun en het commit- 
ment van de Europese Unie en de Verenigde Staten essentieel. Andere delen van de wereld zullen op termijn waarschijnlijk volgen.

Geen wan de drie elementen - institutionele vomgeving van het LASC, de implementatie van de IASs en het afdwingen van de naleving van de LASs - zijn op dit moment naar tewredenheid geregeld en vormen aldus obstakels die een "Esperanto voor de exteme financiéle berichtgeving" in de weg staan. Ik zal die obstakels nu nader belichten.

\section{Totstandkoming International Accounting Standards ${ }^{10}$}

De LASs worden na afwikkeling wan een uitgebreide inspraak- en consultatieprocedure vastgesteld door de IASC-Board. De huidige Boand omvat zestien delegaties met stemrecht: dertien delegaties vertegenwoordigen een land of cen groep landen, wee delegaties vertegenwoordigen de informatieverschaffers en éen delegatie vertegenwoordigt de informatiegebruikers. De dertien landenvertegenwoordigingen worden benoemd door de $\mathrm{FAC}$, terwijl de drie andere delegaties door de Board zelf worden benoemd. Nederland wordt in de Board vertegenwoordigd door het Koninklijk Nederlands Instituut van Registeraccountants (Koninkijk NIVRA). Naast de delegaties met stemrecht woont een viertal delegaties zonder stemrecht de vergaderingen van de Board bij. Deze delegaties vertegenwoordigen China, de Europese Commissie, de Amerikanse Financial Accounting Standards Board (FASB) en de IOSCO. ledere delegatie bestaat uit twee tot vier personen. Dit betekent dat dijdens de vergadeningen van de Board ongeveer zeventig personen om de tafel zitten.

De Board bestaat woor een groot deel uit personen die hun werkzammeden voor het IASC combineren met een drukke batan in de accountantspraktijk of het bedrijfsleven. Zij ontvangen voor hun activiteiten geen honorering. Het aantal keren dat de Board bijeenkomt en de lengte van de vergaderingen is de latste jaren aanmerkelijk toegenomen. In 1998 waren er vijf en in 1999 zullen er wier vergaderingen zijn van elk vier of viff dagen.

ledere ontwerpstandaard (exposure drafi) en definitieve standaard word voor bereid door een ad hoc samengesteld Steering Committee dat bij de werk. zaamheden intensief wordt ondersteund door een stafmedewerker van het IASC-bureau. De $\mathbb{A}$ ASC-Boand keurt ontwerpstandaarden met een tweederde meerderheid en definitieve standaarden met een driekwart meerderheid goed.

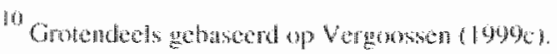


In 1997 is het zogenaamde Standing Interpretations Committee (SIC) opgericht om een consistente interpretatie van de IASs beter te waarborgen. Daartoe doet het SIC an de IASC-Board voorstellen tot het uitgeven van interpretaties (interpretations) dic betrekking hebben op specifieke verslaggevingsproblemen warvoor in de LASs geen of geen eenduidige oplossing is te winden. De Board keurt interpretaties met een driekwart meerderheid goed.

Het huidige institutionele raamwerk waarbinnen de IASs totstandkomen ligt 2wat onder vuur. In 1997 is door de Board een strategiewerkgroep in het leven geroepen, die voorstellen moet doen over de strategie en toekomstige strucuur van het IASC. In de taakopdracht van de werkgroep worden de volgende tekortkomingen van de huidige structurur genoemd of kunnen daaruit worden afgeleid (IASC, 1998, pag. 108):

- besluitvorming tijdens de Board-vergaderingen is niet efficiënt door het grote aantal personen;

- de samenstelling van de Board is niet evenwichtig ondat die feitelijk word bepald door het accountantsberoep (i.c. de IFAC);

- de samenwerking met nationale regelgevende organen is nog niet voldoende ontwikkeld;

- door de sterk toegenomen werkzaamheden wordt het voor de leden varn de Board steeds moeilijker om voldoende tijd vrij te maken.

Ik zal achtereenvolgens ingaan op de oorspronkelijke voorstellen van de straregiewerkgroep, op de belangrijkste kritiek die op deze woorstellen is geuit en op nieuwe voorstellen die zijn gedaan om tegemoet te komen aan de kritiek.

\section{Oorspronkelijke voorstellen}

De strategiewerkgroep publiceerde in december 1998 het discussierapport "Shaping IASC lor the future", waarin voorstellen worden gedaan voor een therziening van de structur van het regelgevende proces binnen het IASC. Datmee trachtre de werkgroep tegemoet te komen aan de tekortkomingen die aan de huidige structuur kleven. Het hoofdthema van het 115 pagina's tellende structurrapport is een "partnership with national standard setters" met als doel de convergentic ussen nationale regelgevingen en IASs te versnellen.

De voorstellen van de strategiewerkgroep voorzagen in een tweekamersysteem. Naast de IASC-Board zon een zogenaamd Standards Development Commitlee (SDC) in het leven worden geroepen. De convergentie tussen nationale regelgewingen en IASs moest met name worden bewerkstelligd door 
het SDC dat zou zijn samengesteld uit een voorziter, zes tot acht leden die tevens stemgerechtigd lid zijn in een nationaal regelgevend orgaan en twee tot vier andere vertegenwoordigers (bijvoorbecld vanuit de verschaffers, gebruikers, accountants). Ten minste zeven leden, waaronder de voorzitter, zouden zich voltijds moeten bezighouden met het opstellen van verslaggevingsregels en de anderen ten minste voor de helft van de tijd. De belangrijkste taak van het SDC zou zijn het ontwikkelen van ontwerpstandaarden en definitieve standaarden. Het SDC moest de Steering Committees gaan vervangen. Een Standards Development Advisory Committee zou als spreekbuis moeten gaan fungeren voor nationale regelgevende organen die niet in her $\mathrm{SDC}$ zitten.

De Board zou volgens de woorstellen van de strategiewerkgroep worden uitgebreid tot 25 delegaties bestaande uit ieder twee personen: twintig landendellegaties waarin vertegenwoordigers van accountantsorganisaties en wijf delegaties met vertegenwoordigers van andere belangenorganisaties. Daarnaast zou een aantal waanemers (zonder stemrecht) aan de vergaderingen mogen deelnemen. De belangrijkste taak van de Board zou bestaan uit het met een gekwalificeerde meerderheid (60\%) goedkeuren wan de door het SDC ingediende ontwerpstandaarden en definitieve standaarden. Afgewezen ontwerpstandaarden en definitieve standaarden zouden worden geretourneerd naar het SDC dat op zijn beurt de desbetreffende stukken - gewijzigd of ongewijzigd - opnieuw bij de Board zou kunnen indienen. Volgens de voorstellen zou dan een gewone meerderheid in de Board voldoende zijn om alsnog tot goedkeuring te komen. De Board zou geen recht van amendement hebben, dat will zeggen de ontwerpstandaarden en definitieve standarden ingediend door her SDC zou de Board niet kumen wijzigen. Bovendien zou de goedkeuring van de interpretaties van het SIC niet meer geschieden door de Board, zoals nu het geval is, maar door het SDC.

In het structuurrapport spelen de Trustees - een soort toezichthoudend orgaan - een belangrijke tol. De Trustees - twaalf in getal - zouden onder meer de leden van het SDC, de Board en het SIC moeten benoemen. Drie Trustees zouden worden benoemd door de IFAC en drie door andere organisaties. De andere helft van de Trustees zou door de Trustees zelf worden benoend. Deze zogenaamde at large Trustees worden geacht niet een bepalde organisatic of een bepald belang te vertegenwoordigen.

\section{Belongrijkste kritiek}

De commentaarperiode op het structuurrapport liep to 30 aprill 1999. Van de mogelijkheid om commentaar te leveren is uitgebreid gebruikt gemaakt. Tal 
wan organisaties en individuen leverden kritiek, waaronder vanuit Noderland het Koninkljk NIVRA dat samen met de Raad voor de Jaarverslaggeving (RJ), de Vereniging VNO-NCW, het Christelijk Nationad Vakverbond, de Federatie Nederlandse Vakbeweging en de Vereniging van Beleggingsanalisten een commentaarbrief schreef.

De belangrijkste punten van kritiek hadden betrekking op:

- de omvang en samenstelling van het SDC: on tot een betere geografische spreiding te komen wordt er vanuit Europa op aangedrongen het aantal zetels in het SDC uit te breiden. De Amerikanen daarentegen willen juist cen klein SDC gemodelleerd naar het voorbeeld van de eigen FASB, dat wil zeggen een beperkt aantal zetels dat wordt bezet door personen die zich voltijds met regelgeving bezighouden en daardoor geheel onafhankelijk zijn. In sommige commentaarbrieven worden vraagtekens gezet bij het voldoende onafhankelijk kunnen functioneren van de SDC-leden die tevens stengerechtigd lid zijn van een nationaal regelgewend orgaan;

- de taakverdeling tussen het SDC en de IASC-Board: de taken van de Board worden volgens velen in Europa uitgehold, terwijl daar in de Verenigde Staten geheel anders over wordt gedacht. De Amerikanen willen een volledig onafhankelijk SDC en vinden het te ver gaan dat de Board een vetorecht heeft, dat wil zeggen dat de Board de ontwerpstandaarden en definitieve standearden moet goedketren alvorens die kunnen worden gepubliceerd. De Europeanen daarentegen vinden dat de ontwerpstandaarden en definitieve standaarden die door het SDC bij de Board worden ingediend, niet alleen door laatstgenoemde moeten worden goedgekeurd maar ook moeten lkunnen worden gewijzigd;

- de achtergronden van de Trustees die onder meer de leden van de Board, het SDC en het SIC zouden moeten benoemen: veel kritiek - met name vanuit Europa - is gekomen op het voorstel om de helft wan de Trustees door middel van een coöptatiesysteem te benoemen. Bovendien zou de Board en niet de Trustees de leden van het SDC en het SIC moeten benoemen. Van verschillende kanten wordt er op aangedrongen dat de IFAC de meerderheid wan de Trustees benoemd, ondat de accountants een onafhankelijke positie innemen ten opzichte wan de opstellers en gebruikers van financiele informatie. Daarnaast zullen zij een sleutelrol spelen bij de controle op de nateving van de IASs;

- de (machts)verhoudingen tussen Europa en de Verenigde Staten binnen de Board en het SDC: Europa is bang dat zij bij uitwoering van de voorstellen veel invloed zal moeten prijsgeven en dat terwijl de IASs in Europa steeds 
meer worden gebruikt. In de huidige Board vertegenwoordigen vijf van de zestien delegaties een land of een groep van landen in Europa. De Amerikanen vinden de Europese invloed op het huidige regelgevende proces te groot. De Verenigde Staten hebben immers slechts één stem. terwijl de Amerikaanse kapitaalmarkt ongeveer weemaal zo groot is als de Europese kapitaalmarkt. In feite zien de Amerikanen Europa als Gén, zeker na de inwerkingtreding van de Economische en Monetaire Unie.

Zoals uit deze - bij lange na niet limitatieve - opsomming naar voren komt. lopen de commentaren sterk uiteen en lijkt een compromis op basis van de oorspronkelijke voorstellen hatast onmogelijk.

\section{Nierswe voorstellen}

Om aan de kritiek tegemoet te komen werden afgelopen zomer tijdens de vergadering van de IASC Board in Warschau nicuwe voorstellen gepresenteend. In deze voorstellen wordt afgestapt van het twee-kamersysteem, dat will zeggen er komt geen SDC. De IASC-Board wordt omgevomd on zal bestaan uit zeventien of vijfentwintig leden: in het eerste geval tien voltijds en zeven deel tijds en in het laatste geval vijftien voltijds en tien deeltijds. Bij de selectie van de leden moeten de kwaliteiten waarover zij beschikken van doorslaggevende betekenis zijn. De nationaliteit van de leden zou daabij in principe een ondergeschikte rol moeten spelen. In de voorstellen is wel aangegeven dat de zetels evenwichtig zouden moeten worden verdeeld over Europa, Noord-Amerika en de rest van de wereld. Bovendien moet de nieuwe IASC-Board een adspiegeling zijn van de partijen die belang hebben bij internationale verslaggevingsregels, zoals nationale regelgevende organen, verschaffers, gebruikers en accountants. Daarbij zal een zekere nadruk liggen op de relatie met nationale regelgevende organen.

De leden van de IASC-Board moeten onafhankelijk zijn, dat wil zeggen dat zij zich niet laten leiden door de belangen van een bepaalde jurisdictie, een bepaald organ of een bepalde groepering. De Trustees zijn verantwoordelijk voor de benoeming van de leden van de IASC-Board en moeten ervoor waken dat de leden van de Board voldoende onathankelijk zijn en dat de samenstelling van de Board evenwichtig is. In tegenstelling tof de oorspronkelifke voorstellen worden de Trustees benoemd door internationale (belangen)organisaties en niet door middel van coöptatie.

Tijens de Warschau-vergadering reageerden alle delegaties positief op de nieuwe voorstellen. Ook de warnemers van de Europese Commissio en de 
FA $\mathrm{SB}$ waren positiel gestemd. Dit laatste is cruciaal voor het welslagen van de gehele operatie. Veel delegaries benadrukten echter dat hun witeindelijke oordeel zal afhangen van de nadere uitwerking van een en ander en van de reactie van hun achterban. De strategiewerkgroep zal de nadere uitwerking ter hand nemen en verwacht wordt dat uitgewerkte voorstellen nog dit najaar zullen worden gepresenteerd. Het is de bedoeling dat in maart 2000 de LASC-Board en twee maanden later de $L A S C$-leden de noodzakelijke wijzigingen in de statuten van het IASC goodkeuren."

Wanneer er uiteindelijk onvoldoende draagvlak mocht zijn - met name in de Europese Unie en de Verenigde Staten - voor de reorganisatie en de daaruit resulterende institutionelle vormgeving van het IASC, is het gevar niet denkbeeldig dat andere organen de rol van global standard-setter gaan vervullen of althans een poging daantoe wagen. De FASB en de zogenaamde G4+1 zouden daarvoor kunnen opteren.

De aandelen van steeds meer Europese ondernemingen zijn genoteerd op effectenbeurzen in de Verenigde Staten. Dil betekent dat hun financiële verslaggeving in principe moet voidoen aan de US GAAP, die over het algemeen veel stringenter zijn dan de IASs. Daardoor neemt de behoefte aan standaarden opgesteld door het IASC bij deze ondememingen af. De tijd lijkt allus in het voordeel te werken van de FASB. In zijn rapport "International Accounting Standard Setting: A Vision for the Future" dat kort na het verschijnen van het rapport van de IASC-strategiewerkgroep is gepubliceerd, dicht de FASB zich een belangrijke rol toe bij de totstandkoming van internationale verslaggevingsregels (FASB, 1999). In het rapport wordt een drietal scenario's geschetst over de wijze waarop naar het oordeel wan de FASB internationale verslaggevingsregels in de toekomst tot stand moeten komen. Eên van die scenario's is het herstructureren van de FASB op een zodanige wijze dat hij - ook buiten de Verenigde Staten - wordt geaccepteerd als internationale regelgevende instan" tie.

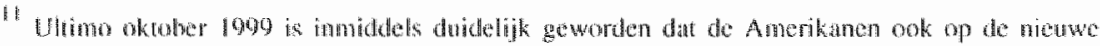

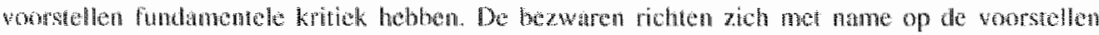

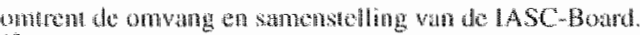

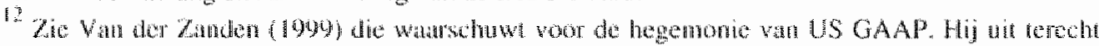

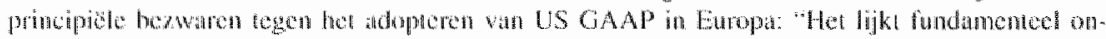

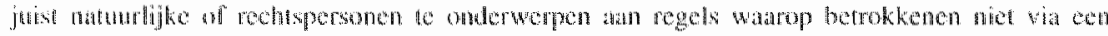

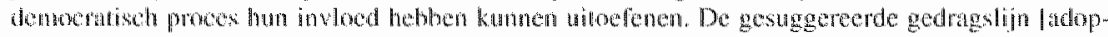

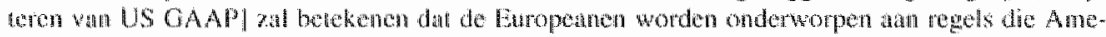

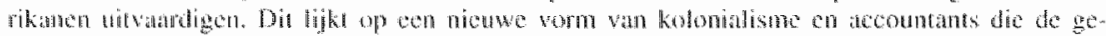


Daarnaast is er nog de mogelijkheid dat een nieuw internationaal regelgevend orgaan wordt opgezet gebaseerd op de G4+1. De G4, dat wil zeggen vertegenwoordigers van de regelgevende organen uit Australiè (en Nieuw-Zeeland), Canada, het Verenigd Koninkrijk en de Verenigde Staten, is aanvankelijk als discussiegroep begonnen. Het LASC $(+1)$ heeft zich indertijd bij de G4 aange sloten onder het motto "if you can't beat them, join them". Onder auspiciern van de $G 4+1$ verscheen inmiddels een aantal discussierapporten en eind vorig jaar is er zelfs een discussierapport uitgezet voor commentaar. Bovendien heef de G4+1 indertijd het initiatief genomen tot het vormen van de Financial Instruments Joint Working Group of Standard-Setters die aan de LASC-Board voorstellen moet doen woor een allesomvattende en permanente standard die te zijner tijd de bestaande standaarden inzake financiële instrumenten (IAS 32 en 39) zot moeten verwangen. Het opzetten van een nieuw internationaal regelgevend orgaan bestaande uit de G4 uitgebreid met vertegenwoordigingen van regelgevende organen uit Duitsland, Frankrijk en Japan moet niet uitgesloten worden geacht. Laatstgenoende landen maken overigens al deel uit van de Joint Working Group."

Het is evident dat het welslagen van de reorganisatie van het LASC en de wijze van totstandkoming van IASs van doorslaggevende betekenis is voor de toekomst van het IASC als global standard-setser. De nieuwe structuur moet aanvaardbaar zijn voor nationale en regionale regelgevende organen (waaronder de Europese Commissie) en voor nationale beurzen en beurstoezichthouders. Dit is een noodzakelijke voorwaarde om te komen tot een erkenning van de IASs door genoemde partijen. Daarbij zullen overigens ook de waarborgen die moeten leiden tot een consistente implementatie, interpretatie en toepassing van de IASs, alsmede een consistente controle door accountants en toezichthouders op de naleving daarvan een belangrijke rol spelen.

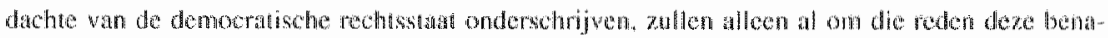
deringswijae moeten verwerpets" (pag. 300 ).

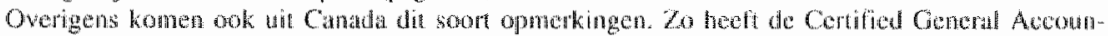
tants Association of Canda (1999) recentelijk cen rapport abtgobuch watrin het overamen wam

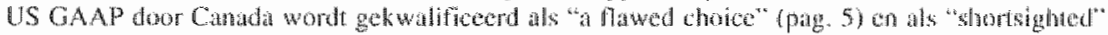
(pag. 7. Zij beveell aan do 1 ASs awe to nemen en to sloppen met hot opstallen wan eigen standaarden.

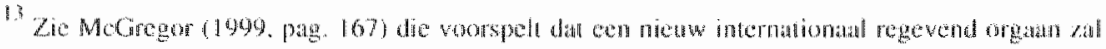

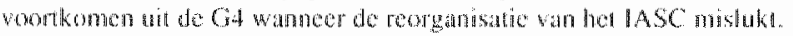




\section{Implementatie International Accounting Standards}

De implementatie van de IASs is op dit moment in belangrijke delen van de wereld niet énvormig. In grote lijnen kunnen we ver manieren onderscheiden warop landen of juridicties met de IASs ongan:

1. de IASs zijn tevens de nationale standaaden. Deze handelwijze zien we met name in ontwikkelingslanden en landen die behoren tot het voormalige Oostblok. Door de overgang naar een markteconomie en de voortgaande internationalisering van het bedrijfsleven is in dit soort landen de betoefte aan regelgeving omirent de externe financiele berichtgeving ontstaan. Het zal duitelijk zijn dat het zonder of slechts met kleine wijzigingen overnemen van de JASs voor deze landen efficiënter en wellicht ook effectiever is dan het zelf ontwikkelen van verslaggevingsregels:

2. in bepaalde gevallen, voor bepaalde onderdelen en onder bepaalde voorwaarden is de toepassing van de IASs vereist of toegestaan. Dit is in feite wat ten aantal landen van de Europese Unie heeft gedaan, waaronder Duits.and en Frankrijk. Zoals eerder besproken, mogen beursgenoteerde ondernemingen in deze landen onder bepaalde voorwaarden de IASs toepassen;

3. de IASs worden zoveel mogelijk verwerkt in bestaande of nieuwe nationale regelgeving. Het is evident dat tussen de landen die deze politiek aanhangen belangrijke varschillen kunnen bestaan in de mate waarin de nationale regelgeving afwijkt van de IASs. Nederland kumen we tot deze categorie rekenen, aangezien de RJ de IASs als uitgangspunt neemt bij het opstellen c.q. aanpassen van de Richtlijnen woor de jaarverslaggeving (RJrichtlijnen). Daarbij zijn afwijkingen van IASs in een apart hoofdstuk van de richtlijnenbundel opgenomen;

4. de ontwikkeling van nationale standaarden loopt parallel aan de ontwikkeling vall IASs, bijwoorbeeld doordat én of meer landen samen met het IASC regelgewing ontwikkelen. Het betreft met name regelgevers uit Angelsaksische landen die op dere manier samenwerken met het IASC. Zo hebben de Canadezen met het IASC samengewerkt bij de totstandkoming van een standaard op het gebied van financiele instrumenten, de Britten op het gebied van woorzieningen en de Amerikanen op het gebied van gesegmenteerde informatieverschaffing en winst per aandeel. Het lijkt er overigens op dat de nationale regelgevers de inhoud van de desbetreffende lASs voon ten belangrijk deel bepalen en niet omgekeerd! 
Het blijkt dat de verschillen zich niet alleen manifesteren langs de lijnen van wereldelen, maar dat ook tussen westerse landen onderling op uiteenlopende wijzen wordt omgegaan met de IASs. Daarbij kan een parallel worden getrokken met het hiervoor als figurr 3 opgenomen schema van Nobes inzake linternationale verschillen in verslaggevingssystemen; aan de ene kant de landen met relatief sterke kapitaalmarkten en een wijdverspreid aandelenbezit, dat wil zeggen de Angelsaksische landen en Nederland warop variant 3 of 4 van toepassing is, en aan de andere kant de landen met relatief minder sterke kapitaalmarkiten en een belangrijke invloed van de banken en de overheid, bijvoorbeeld Duitsland en Frankrijk waarop variant 2 van toepassing is.

De uiteenlopende manieren waarop de IASs worden geïmplementeerd in de nationale regelgevingen en het gebrek aan coördinatie daarvan, werkt problemen ten aanzien van de interpretatie en de toepassing van de IASs in de hand. De interpretaties die worden opgesteld door het SIC zullen waarschijnlijk in toenemende mate een bijdrage leveren aan een consistente implementatie van de IASs. Bovendien wil het IASC in de toekomst bij iedere standaard achtergrondinformatie en minderheidsstandpunten publiceren, hetgeen de implementatie verder kan faciliteren (Carsberg, 1999, pag. 442).

Bij de bespreking van de LASC-tempel heb ik aangegeven dat pas wanneer de Verenigde Staten en de Europese Unie - de twee buttenste zuilen - tot erkenning c.q. implementatie van de IASs overgaan, het IASC kan worden gekwalificeend als global standard-setter.

In zal nu wat dieper ingaan op die twee buitenste zuilen. In het verlengde van de Europese Unie zal ik bovendien bespreken hoe Nederland met de IASs zou moeten omspringen.

\section{Verenigde Staten}

Zoals ik zojuist heb aangegeven, start de SEC niet te trappeten om tof erkenning wan de LASs over te gaan en als zij al daartoe besluit dan zal die erkenning alleen maar gelden voor niet-Amerikaanse ondemeninger. De SEC verlangt op dit moment van buitenlandse ondernemingen nog dat zij hun financiẻle informatieverschaffing in overeenstemming brengen met de over het algemeen veel stringenter geformuleerde US GAAP. Dit betekent dat erkenning van de IASs door de SEC zou leiden tot een versoepeling van de woorwaarden die gelden voor beursnoteringen van niet-Amerikanse ondernemingen met als gevolg dat - in de. ogen van de SEC - een zekere concurrentievervalsing optreedt ten opzichte van 
de eigen (Amerikaanse) ondernemingen, omdat die moeten blijven voldoen aan de strenge US GAAP.

De SEC is van mening dalt zij witsluitend tot erkenning van de IASs kan overgaan wanneer die allesomvattend zijn, van hoge kwaliteit zijn en sirikt worden geinterpreteerd en toegepast. Dat kont er feitelijk op neer dat de IASs aan dezelfde kwaliteitsnormen moeten voldoen als de eigen verslaggevingsregels of om met de woorden van Arthur Levitt, de voorzitter van de SEC, te spreken: "International Accounting Standards need not be US GAAP, but in terms of quality, comparability and werifiability they must be no less." eens vaak bijzonder kritisch uit over de kwaliteit van de IASs."

In de Verenigde Staten gaan ook stemmen op dat de SEC niet te halsstarrig aan haar standpunt moet vasthouden. De New York Stock Exchange bijwoorbeeld, heeft te kennen gegeven dat de SEC water bij de wijn moet doen om te voorkomen dat de concurrentieslag met buitenlandse beurzen wordt verloren als gevolg van de strengere eisen die worden gesteld aan de informatieverschaffing. Uit recent onderzoek blijkt bovendien dat een overgrote meerderheid van de portefeuillebeheerders in de Verenigde Staten voorstander is van een overgang naar LASs. ${ }^{16}$ Voorts is enkele jaren geleden een wet aangenomen waarin onder andere is vastgelegd dat de SEC zich (nog) meer dan voorheen moet inspannen voor de totstandkoming van internationale verslaggevingsnormen. ${ }^{17}$

Of de SEC uiteindelijk zal overgaan tot een erkenning van de LASs is nog ongewis. "*

\section{Europese Unie}

Sinds de publicatie in 1995 van de eerdergenoemde Mededeling van de Europese Commissie inzake een nieuwe strategie ten aanzien van de internationale harmonisatie, is hevig gediscussicerd over de wijze waarop in de Europese Unie met de IASs moet worden omgegaan. Het woorstel om ondernemingen IASs te laten toepassen, herhaalt de Europese Commissie in Mededelingen die in 1998 en 1999 zijn verschenen $(1998,1999$ a; $)$. Het zag er enige tijd naar uit

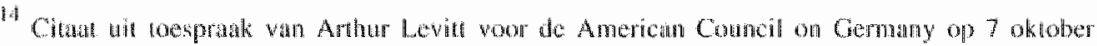
1999 in New York.

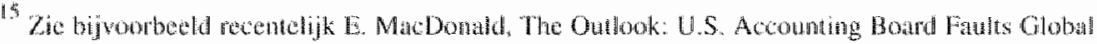

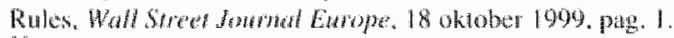

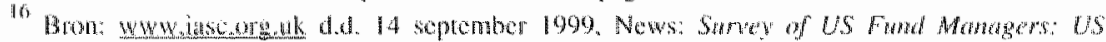

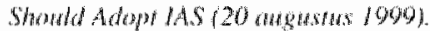

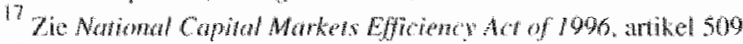

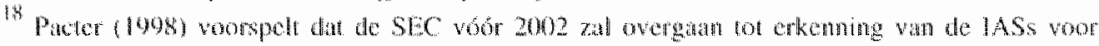

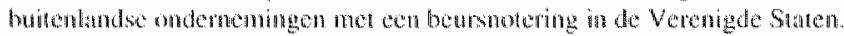


dat de Europese Commissie de optie om IASs toe te passen zou omzetten in een verplichting, maar is daar weer van teruggekomen. De Europese Commissie komt eind dit jaar met een definitief standpunt en met voorstellen tot wijziging van de EEG-richtlijnen (Europese Commissie, 1999a, pag. 5).

De Europese Commissie zal naar verwachting uiteindelijk voorstellen om an beursgenoteerde ondernemingen de optie te geven hun geconsolideerde jaarrekening op stellen in overeenstemming met IASs met dien verstande dat in geval van strijdigheden met de EEG-richtijnen zij de invloed daarvan op de gepresenteerde cijfers moeten aangeven. Wordt voor deze optie gekozen dan behoeft de onderneming de geconsolideerde jaarrekening niet meer op te stellen volgens de (op de EEG-richtlijnen gebaseende) nationale verslaggevingstegels. Wanneer de onderneming echter geen gebruikmaakt van de optie en de geconsolideerde jaarrekening moet worden opgesteld in overeenstemming met de nationale verslaggevingsstandaarden dan zal daarnaast - in de vorm van aansluitingsoverzichten (reconciliation statements) - toch ook informatie moeten worden verstrekt op basis van IASs. Dit betekent dat ondernemingen in teder geval informatie moeten verstrekken op basis van IASs, waardoor zij beter met elkaar kunnen worden vergeleken.

Desalniettemin zouden dergelijke voorstellen van de Europese Commissie in mijn visie niet ver genoeg gaan. Implementatie van de IASs op Europees niveau kan naar mijn mening het beste worden gerealiseerd door middel van een voorschrift dat alle beursgenoteerde ondernemingen verplicht hun geconsolideerde jaarrekening op te stellen in overeenstemming met IASs. Daarbij behoeft dan niet tevens informatie te worden opgenomen gebaseerd op de EEGrichtlijnen of de nationale wettelijke bepalingen. Dit voorkomt dat ondernemingen in geval van afwijkingen zijn genoodzaakt aansluitingsoverzichten op te stellen, hetgeen leidt tot hogere administratieve lasten en mogelijk tot verwarring bij de jaarrekeninggebruikers. Bovendien zouden de EEG-richtlijnen en de nationale wettelijke bepalingen continu moeten worden aangepast naar aanleiding van nieuwe of gewijzigde IASs die daarmee strijdig zijn. Dit om te voorkomen dat zij steeds meer van de IASs gaan afwijken.

De Fédération des Experts Comptables Européens (FEE) - de Europese accountantsberoepsorganisatie - die zich zeer recentelijk in de discussie heeft gemengd met de publicatie van een discussierapport over onderhavige problematiek, stelt overigens voor om een Europees orgaan in het leven te roepen dat onder meer de toepasbaarheid van de IASs in een Europese context doorlopend zou moeten screenen en waar de Europese Commissie in haar regelgeving aan 
kan refereren (FEE, 1999b, pag. $11-4)^{19}$ Dit laatste is op juridische gronden kennelijk niet goed mogelijk met een uit particuher initialief ontsproten organisatie als het IASC. Het Europese orgaan - European Financial Reporting Coordination and Advisory Council genoemd - zou een privaatrechtelijk karakter moeten hebben en onathankelijk doch onder toezicht van de Europese Commissie moeten opereren. Dit orgaan zou moeten fungeren als een soort vangnet en alleen in uitzonderlijke situaties aanwijzingen moeten geven om van IASs af te wijken. Het is daarbij in ieder geval niet de bedoeling dat het orgaan in concurrentie treed met het SIC van het IASC door het publiceren van eigen "Europese" interpretaties.

\section{Nederland}

Hoe in Nederland moet c.q. kan worden omgegaan met de IASs, zal voor een groot deel worden bepaald door Brussel. In een recent verschenen artikel beschrijven Van Helleman en Klaassen (1999, pag. 447-8) drie opties die Nederland binnen de huidige Europese regelgeving heeft, hoe om te gaan met de IASs:

1. het handhaven van de huidige situatie, dat wil zeggen de wet wordt onverkort gehandhaafd en de RJ-richtijnen vormen het referentickader voor de normen die maatschappelijk als aanvaardbaar worden beschouwd. De IASs worden in de RJ-richtijnen geincorporeerd voor zover zij acceptabel worden geacht. In deze optie kunnen de IASs dus niet rechtstreeks en onverkort worden toegepast;

2. de wet blijft van kracht, maar de 1 ASs worden naast de RJ-richtlijnen erkend als maatschappelijk aanvaardbare normen. On strijdigheid met de IASs te vermijden, zou de wet kunnen worden aangepast. Deze aanpassing kan niet verdergaan dan de EEG-richtlijnen toestaan, zodat onverkorte toepassing van de LASs niet in alle gevallen mogelijk zal zijn;

3. in tawolging van Duitsland, Frankrujk en een aantal andere lidstaten van de Europese Unie word het beursenoteerde ondernemingen toegestaan IASs te volgen, voor zover die niet in strijd zijn met de EEG-richtijnen.

Van Helleman en Klaassen zien de derde optie als een reéle mogelijkheid zeker wanneer de EEG-richtijnen zouden worden aangepast om strijdigheden

19 Zie rok Guropese Commishe (1099. pag. In watrin word gesproken over "A werenng me-

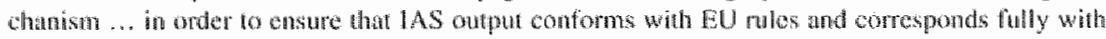
EU public policy coneths."

Zio ouk Van der Tas (1995). 
met de IASs te vermijden. Hierdoor zou volledige toepassing van de IASs door beursgenoteerde ondernemingen mogelijk worden. Het steeds weer opnieuw aanpassen van EEG-richtlijnen en nationale wetten om in lijn te blijven met aangepaste LASs is omslachtig en tijdrovend en mijns inziens dan ook niet to prefereren.

Een verdergaande optie waarbij de EEG-richtlijnen en de daarop gebaseerde nationale wetgewingen voor de beursgenoteerde ondernemingen teraijde worden geschoven ten gunste van de IASs vinden Van Helleman en Klaassen ongewenst, ondat daardoor een belangrijk vacuitm zou worden gecreèerd met betrekking tot onderwerpen die nog niet door IASs zijn afgedekt. Uit het voor gaande moge duidelijk zijn dat ik het met deze zienswijze niet eens ben. Bovendien dekken ook de huidige EEG-richtlijnen en nationale wetgevingen niet alle onderwerpen af.

De implementatie van de LASs geschiedt in Nederland op dit moment dus door het verwerken van deze standaarden in de RJ-richtlijnen. De RJ is een tripartiet samengesteld privaatrechtelijk orgarn "bestaande uit vertegenwoordigers van de verschaffers, de gebruikers en de controleurs van externe financiële berichtgeving. De Nederlandse wet biedt niet de mogelijkheid om onder bepatide voorwaarden de IASs toe te passen, zoals bijvoorbeeld in Duitsland en Frankrijk. In Nederland wordt een dergelijke faciliteit niet nodig geacht ondat de Nederlandse wet flexibel genoeg zou zijn om de IASs zonder problemen te kunnen toepassen. ${ }^{21}$ Bij de implementatie van IASs in de RJ-richtlijnen lijken gaandeweg steeds vaker fricties te ontstaan. De RJ-Richtlijnen worden namelijk uitgevaardigd op basis van consensus. Hoewel gezaghebbend, kan de naleving van de RJ-richtlijnen vanwege hun privaatrechtelijke status niet worden afgedwongen. Door de implementatie van de stringent geformuleerde IASs worden opties die de Nederlandse wet biedt aanmerkelijk ingeperkt. Hier lijkt vooral de verschaffersdelegatie in de RJ enigszins moeite mee te hebben. Bo-

20 Oxtrigens zou kunnen worder betoogd dat beptalde ondernemingen nat de latrer van de wa

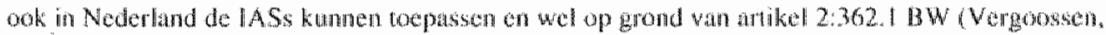

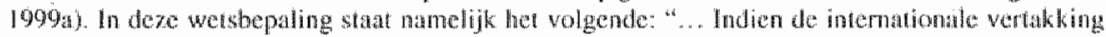

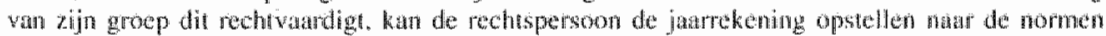

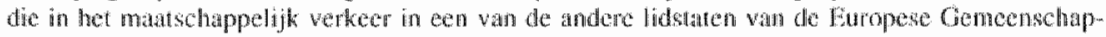

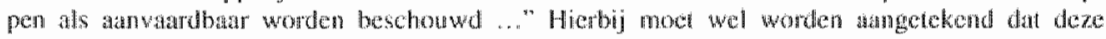
bepaling wdertijd in te wet is opgenomen on ondenemingen dis behoren lon aen butentandse



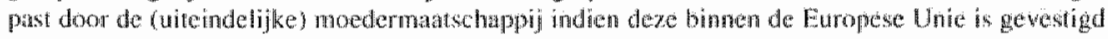
(Rechspersonen, wurplement 96 rok tober 1990 ) antikel $362-36-45$ ). 
vendien wil de RJ zoveel mogelijk binnen het bestaande wettelijke kader opereren, waardoor er problemen ontstan met de implementatie van IASs die strijdigheden met de Nederlandse wet in zich bergen.

De wije watrop de IASs in Nederland worden geimplementeerd is in mijn visie halfslachtig en omslachig. Halfslachtig, omdat de RJ op basis van consensus $\mathbb{R J}$-richtlijnen utvaardigt en de $\mathbb{R J}$ noodzakelijkerwijs opereert bimen het bestaande wettelijk kader. Hierdoor treedt or een zekere verwatering op van de IASs bij de implementatie in de RJ richtlijnen. Omslachtig, omdat rechtstreekse toepassing van de IASs door Nederlandse beursgenoteerde ondernemingen geen probleem zou moeten zijn.

In het verlengde van hetgeen ik zojuist heb besproken in een Europees kader, zouden in mijn visie alle Nederlandse beursgenoteerde ondernemingen moeten worden verplicht de $\mathrm{IAS}$ s toe te passen bij het opstellen van hun geconsolideerde jaarrekening. Dit zou door middel van een wettelijk voorschrift kunnen of door middel van een voorschrift uitgevaardigd door de Amsterdam Exchanges of de Stichting Toezicht Effectenverkeer. Het moge echter duidelijk zijn dat de mogelijkheden die de Nederlandse wetgever heef, worden bepaald door de speclruimte die de Europese Commissie de lidstaten geeft. Interessant in dit kader is een brief van de minister van Financiën aan de Tweede Kamer, waarin het kabinetsstandpunt staat verwoord dat het voor international opererende ondenemingen onder bepaalde voorwaarden mogelijk moet zijn om, voor zover de EEG-richtlijnen dit toestaan, internationaal aanvaarde standaarden toe te passen, zoals IASs en US GAAP. Hierbij word aangegeven dat daartoe indien nodig - de wet zal worden aangepast. ${ }^{22}$ Kortom, het kabinet overweegt een soortgelijke regeling als bijvoorbeeld in Duitsland en Frankrijk. De Amsterdam Exchanges meent dat de Nederlandse wet zodanig moet worden aangepast dat de effectenuitgevende instellingen met het gebruik van de IASs kunnen volstaan (Amsterdam Exchanges, 1999, pag. 41-2).

Overigens heeft de minister van Justitie al in 1986 de IASs expliciet erkend als gelijkwardig aan de Zevende EEG-richtlijn. Dit legde hij vast in de "Regeling gelijkwaandigheid van voorschriften voor jaanekeningen". Op verzoek van de Europese Commissie echter heeft Nederland enkele jaren later deze regeling weer ingetrokken. In die tujd was er in andere lidstaten geen sprake van een soortgelijke regeling. ${ }^{2}$ Gezien de buidige discussie in de Europese Unie om-

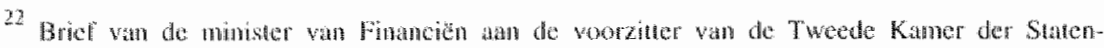

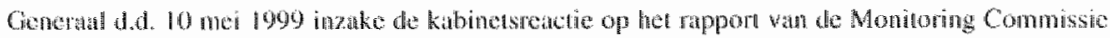

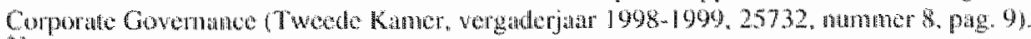

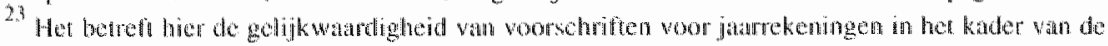


trent de erkenning van de lASs en de wetsbepalingen in een antal lidstaten die de toepassing van de LASs - onder bepaalde voorwaarden - toestaan, moeten we het Nederlandse beleid in het midden van de jaren tachtig tier zake toch ats zeer vooruitstrevend bestempelen.

Rechtstreekse toepassing van de IASs door Nederlandse beursgenoteerde ondernemingen zou betekenen dat er op dat vlak geen rol meer is weggelegd voor de RJ als regelgevend orgaan. Dit betekent overigens niet dat de RJ geen bestaansrecht meer zou hebben. Integendeel, zeker nu in LASC-verband gestreefd wordt naar een "partnership with national standard setters" liebben we juist een sterke nationale regelgever nodig die kan participeren in de totstandkoming van internationale standaarden en die zich kan meten met de nationale regelgevende organen in de belangrijkste Europese landen. Bovendien zou de RJ moeten participerem in de European Financial Reporting Coordination and Advisory Council, het nog in het leven te roepen gremium op Europees niveau. Daarnaast blifft er voor de RJ een belangrijke rol weggelegd voor regelgeving inzake de vennootschappelijke jaarrekening, de externe financiële berichtgeving door niet-beursgenoteerde ondernemingen en door ondernemingen en instellingen die in specifieke sectoren werkzaam zijn, bijvoorbeeld pensioenfondsen, beleggingsinstellingen en commerciële verenigingen en stichtingen. ${ }^{24}$ Voor miet-beursgenoteerde ondernemingen zou de $\mathrm{RJ}$ er in mijn visie voor moeten kiezen om de IASs in principe én op éérn te implementeren in de RJrichtlijnen. Dit om de verschillen met de beursgenoteerde ondernemingen zoveel mogelijk te beperken. Slechts bij wijze van uitzondering zou mogen worden afgeweken van IASs, bijvoorbeeld wanneer die strijdig zouden zijn met de EEG-richtlijnen; zoals hiervoor besproken, zullen de EEG-richtlijnen van toepassing blijven voor niet-beursgenoteerde ondernemingen. Als voorbeeld kan dienen de wijze waarop in Nederland door het Koninklijk NIVRA de International Standards on Auditing (ISAs) in de Richtlijnen voor de Accountantscontrole (RAC) zijn geimplementeend. De RAC zijn in principe een woordelijke vertaling van de ISAs. De afwijkingen van de ISAs worden in de RAC duidelijk aangegeven door middel van zogenaamde A-paragrafen. Han-

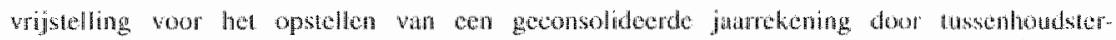

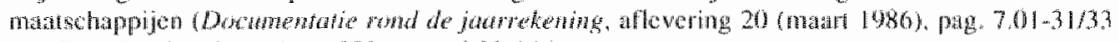
en aflevering 34 (december 1989 ), pag. 6.02-164).

${ }^{24}$ Zie ook de enige tijd geteder gevoende discussie tugen Cantferman \& De Wih (1996) en Wan

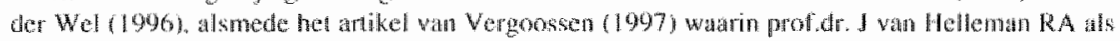
worzitter vas de RJ zijn moning geeft. 
dicap van de $\mathrm{RJ}$ blifft dat de naleving van de $\mathrm{RJ}$-richtlinen niet kan worden afgedwongen. De drie delegaties in de RJ zouden zich wel duidelijk moeten. committeren aan een dergelijke strategische keuze. ${ }^{25}$

De invloed van een integrale toepassing van de $\mathrm{LASs}$ op de door Nederlandse ondernemingen gepresenteerde cijfers en in de toelichting opgenomen informatie kan overigens zeer groot zin. De toepassing van de LASs zal vaak leiden. tot (Vergoossen, 1999d):

- een lager resultaat:

- en hoger eigen vermogen;

- minder rechtstreakse mutaties in het eigen vermogen;

- minder buitengewone baten en lasten;

- grotere fluctuaties in het patroon van het nettoresultaat en het resultaat wit gewone bedrijfsuitoefening;

- minder wijzigingen in de grondslagen van waardering en resultaatbepaling:

- meer informatie in de toelichting.

Bij veel Nederlandse ondernemingen zal de toepassing wan de IASs leiden tot Jagere winstcijfers en een hoger eigen vermogen. Dit wordt vooral veroorzaakt doordat de bij acquisities betaalde goodwill volgens de IASs moet worden geactiveerd en vervolgens afgeschreven, terwijl de meeste Nederlandse ondernemingen de betalde goodwill nog steeds in én keer rechtstreeks ten laste van thet eigen vermogen brengen.

In de tijd gezien zal toepassing van de IASs leiden tot grotere fluctuaties in de gepresenteerde resultaten. Dit geldt zowel voor het nettoresultaat als voor het resultaat uit gewone bedrijfsuitoefening. Vooral de strengere criteria die wolgens de IASs gelden voor het opnemen van voorzieningen en de zeer beperkte mogelijkheden van rechtstreekse mutaties in het eigen vermogen en het opnemen van buitengewone posten in de winst- en verliesrekening zijn hier debet aan.

Toepassing van de IASs perkt het aantal opties in dat de Nederlandse wet- en regelgeving kent. Dit betekent dat er voor Nederlandse ondernemingen minder keuzemogelijkheden blijwen bestaan, hetgeen impliceent dat het aantal wijzigingen in de grondslagen van waardering en resultatbepaling zal afnemen.

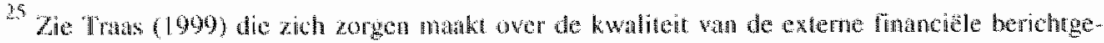

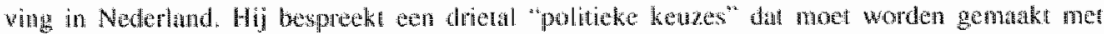

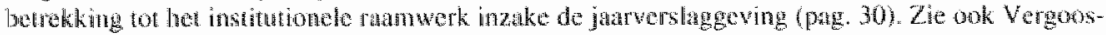
sen (1999b).
} 
Esperanto of Babylonische spradverwaring? | 41

Doordal de IASs vergeleken met de huidige Nederlandse wet- en regelgeving on meer en gedetailleerder informatie vagen, wal toepassing van de IASs leiden tot een aanzienlijke uitbreiding van de informatieverstrekking in de toelichting.

\section{Naleving International Accounting Standards}

Dan is er nog het vraagstuk met betrekking tot de controle op de naleving (enforcement) van de LASs. Idealiter zou een mechanisme moeten worden opgezet dat erin voorziet dat wereldwijd een consistente interpretatie en toepassing van de LASs wordt afgedwongen. Het is immers van cruciaal belang dat verslaggevingsregels die als wereldstandaard moeten fungeren niet alleem wereldwijd worden voorgeschreven of geimplementeerd, maar ook wereldwijd worden nageleefd. Hierbij is primair een rol weggelegd voor het accountantsberoep en - voor zover het beursgenoteerde ondernemingen betreft - tevens voor de beurstoezichthouders.

Het is evident dat het de verantwoordelijkheid van ondernemingsleidingen is dat de LASs adequaat worden toegepast. De taak van de controlerende accountants is om dit te verifièren en over de bevindingen in de vorm van een accountantsverklaring mededeling te doen. Vanwege de eerdergenoemde intemationalisering van het bedriffsleven en globalisering van de kapitaalmarkten, is het evenwel van cruciaal belang dat die accountantscontrole wereldwijd op dezelfde manier plaatsvindr. Het is dan ook toe te juichen dat binnen het dit jaar in het leven geroepen International Forum on Accountancy Development, de vijf grootste internationale accountantskantoren (Big Five) een project zijn gestart dat er onder meer op is gericht on de kwalliteit van de accountantscontrole wereldwijd te verbeteren en ten minste op een bepaald minimumniveau te brengen. ${ }^{26}$ De ISAs - opgesteld door IFAC's International Auditing Practices

\footnotetext{
26 Het Intemational Forum on Accountatey Deselopment is in jumi 1909 door de 18 A C in hat

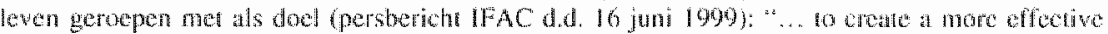

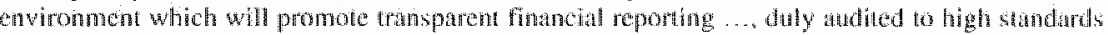

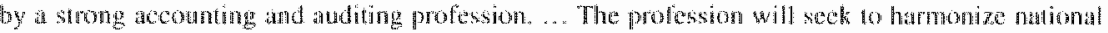

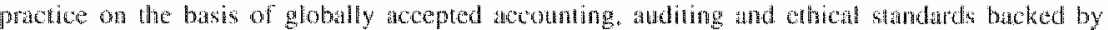

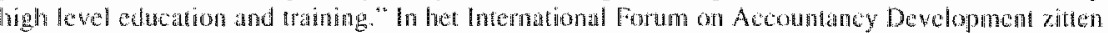

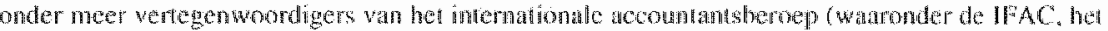

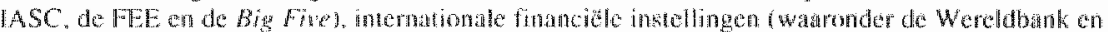
het Internationast Monetair Fonds) wn andere internat ionate orgunisabes (watander de 10500 en de Europese Commision.
} 
Committee - zouden daarbij als minimumeis gelden. In de accountantsverklaring zou de accountant moeten aangegeven in hoeverre de IASs zijn nageleefd. Dat verbeteringen op dit wak nodig zijn, blijkt onder meer uit een studie van Street, Gray \& Bryant (1999). In het onderzoek komt naar voren dat relatief veel ondernemingen op belangrijke onderdelen niet voldoen aan de IASs. terwijl zij cat in hun jaarekening wel zeggen te doen en/of in de accountantsverklaring wordt gesteld dat de IASs worden nageleefd ${ }^{27}$ Het LASC zelf heeft overigens wercldwijd 827 ondernemingen en andere organisaties geidentificeerd die in hun jaarrekening zeggen de IASs integraal toe te passen.

Natast het accountantsberoep is met betrekking tot beursgenoteerde ondememingen een belangrijke rol weggelegd voor de beurstoezichthouders ten aanzien van het afdwingen van de naleving van de IASs. Daarbij zou kunnen worden gedacht aan een orgaan dat wereldwijd toezicht houdt op alle beurzen. Het zal duidelijk zijn dat een dergelijk mechanisme als gevolg van de sterk afwijkende rechtstelsels in de verschillende landen op de korte of middellange termijn niet in het verschiet ligt. Wellicht dat de IOSCO - dat op dit moment hatar leden alleen aanbevelingen kan doen en geen woorschriften kan uitvaardi gen - op dit vlak in de toekomst een rol zou kunnen vervullen.

In afwachting van de ideaaloplossing, zal implementatie van de IASs in de Europese Unie gepaard moeten gaan met het opzetten van een mechanisme waarmee de naleving van deze standaarden door beursgenoteerdle ondernemingen wordt afgedwongen. De wijze waarop en de effectiviteit waarmee in de lidstaten van de Europese Unie de naleving van verslaggevingsregels word afgedwongen zijn op dit moment nog sterk uiteenlopend. De verschillen manifesteren zich onder meer op de volgende terreinen:

- de aard van de ondernemingen die zijn onderworpen aan een mechanisme waarmee de naleving wordt afgedwongen: alleen beursgenoteerde ondernemingen, zoals bijwoorbeeld in Finland, Italië en Oostenrijk of ook nietbeursenoteerde ondernemingen, zoals bijwoorbeeld in Frankrijk. Nederland en hel Verenigd Konnkrijk;

- het orgaan dat de naleving afdwingt: ten anzien van beursgenoteerde ondernemingen is dat de beurstoezichthouder, zoals bijvoorbeeld in Belgie.

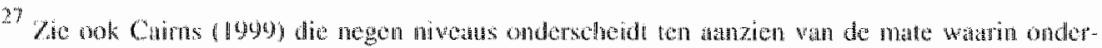
nemingen de ASs lowensisen.

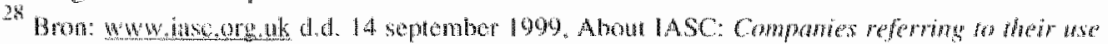
of 14.5 .
} 
Frankrijk en Italië of de effectenbeurs zzelf, zoals bijvoorbeeld in Oostenrijk, het Verenigd Koninkrijk en Zweden;

- de opzet van het mechanisme waarmee de naleving wordt afgedwongen: systematisch, zoals bijworbeeld in Belgiè en ltalie, steekproefsgewijs, zoals bijvoorbeeld in Denemarken en Frankrijk of naar aanleiding van klachten, zoals bijvoorbeeld in Nederland en het Verenigd Koninkrijk.

Het opzetten van een goed functionerend mechanisme waarmee de naleving Wan vers Jaggevingsregels wordt afgedwongen, is overigens ook van essentieel belang in het kader van de voortgaande integratie van de kapitaalmarkten in Europa als gevolg van de introductie van de euro en daarmee de inwerkingtre ding van de Economische en Monetaire Unie. Tussen de belangrijkste Europese beurzen vinden al enige tijd gesprekken plaats om te komen tot een nawwe samenwerking, die mogelijkerwijs uitmondt in de oprichting van en panEuropese effectenbeurs (Steenbeek, 1999). Indien dat laatste zich voordoet zal er ook behoefte zijn aan een pan-Europese beurstoezichthouder, die onder meer toeziet op de naleving van de verslaggevingsregels. Die pan-Europese beurstoezichthouder zou overigens kunnen worden gemodelleerd naar de Amerikaanse SEC.

In cle tussentijd echter is het voor een consistente toepassing van de IASs in de Europese Unie noodzakelijk dat het toezicht op de naleving van deze standaarden op Europees niveau word gecoördineerd. Het Forum of European Securities Commissions (FESCO), de Europese organisatie van beurstoezichthouders, zou hier een centrale rol kunnen vervullen als coördinator van werkzaamheden van de nationale beurstoezichthouders. De FEE (1999b, pag. 12) geeft in haar rapport aan dat daarnaast een systeem van klachtenbehandeling onderdeel zou kunnen uitmaken van het mechanisme dat de naleving van de IASs moet afdwingen. De European Financial Reporting Coordination and Adwisory Council zou dan kunnen fungeren als de instantie waar belangheb. benden hun klachten kwijt kunnen over de externe financiële berichtgeving door ondernemingen. Het zou ook kunnen opereren als cen soort review panel dat op eigen initiatief de kwaliteit van de exterme financiěle berichtgeving op een meer systematische wijze screent. 


\section{Esperanto of Babylonische spraakverwarring?}

Dan kom ik nu tot een afronding van mijn betoog. Intemational Accounting Standards: Esperanto of Babylonische spraakverwarring? ...

Ik hoop dat ik duidelijk heb gemaakt dat na de finale afronding in decernber 1999 van de set van kernstandaarden, nog een aantal belangrijke obstakels uit de weg moet worden geruimd alvorens het IASC de rol van global standardseter vervult en de standaarden die zij uitgeeft als het "Esperanto voor de exicine financiële berichtgeving" kunnen worden beschouwd. Zoals besproken hebben die obstakels betrekking op:

- de institutionele wormgeving van het LASC en de wijze waarop daarbinnen de standaarden totstandkomen en worden onderhouden;

- de wijze waarop de implementatie van de standaarden in belangrijke delen van de wereld platsvindt en een consistente interpretatie en toepassing is gewaarborgd;

- de wijze waarop de naleving van de standaarden wordt afgedwongen.

Voor wat betreft de institutionele vormgeving van het IASC en de wijze waarop de standaarden in de toekomst totstandkomen zijn het afgelopen jaar goede worderingen gemakkt. Hopelijk kunnen nieuwe voorstellen van de sirategiewerkgroep rekenen op voldoende steun en commitment vanuit de Verenigde Staten, de Europese Unie en andere delen van de wereld, zodat het fundament woor de [ASC-tempe] is gelegd. Dat is onontbeerlijk om te komen tot een goedwerkend "Esperanto voor de externe financiële berichtgeving". In leder geval moet worden voorkomen dat de IASs hetzelfde lot is beschoren als de in 1887 door de Poolse oogarts Lazarus Ludwig Zamenhof gepubliceerde "Lingvo Internacia". De "Lingwo Internacia" - het oorspronkelijke Esperanto - is een mengeling van met name Germaanse en Romaanse talen. Deze internationale kunsttaal was bedoeld als wereldtaal maar moest het afleggen tegen de spontaan in belang toenemende Engelse taal toen het draagvlak ervoor ontbrak. De implementatie van de IASs - de zuilen van de tempel - is op dit moment niet eênvormig en in belangrijke delen van de wereld gebrekkig en zij worden mede daardoor niet consistent geinterpreteend en toegepast. Het gevaar van een Babylonische spraakverwarring is dan ook niet denkbeeldig doordat de IASs in verschillende jurisdicties of zelfs binnen én jurisdictie op verschillende manicren worden geimplementeerd, geïnterpreteerd en toegepast.

We kumnen de IASs in mijn ogen alleen mar zien als wereldstandaard wanneer ze ten minste in de Verenigde Staten en de Europese Unie moeten worden 
toegepast door alle beursgenoteende ondenemingen bij het opstellen van hun geconsolideerde jaarrekening. In de Verenigde Staten is erkenning van de IASs woor alle - Amerikaanse en niet-Amerikaanse - beursgenoteerde ondernemingen echter niet te verwachten. Het zou echter een stap in de goede richting zijn wanneer die erkenning wel zou gelden woor niet-Amerikaanse ondernemingen die op een Amerikaanse beurs zijn genoteerd. In de Europese Unie zou de implementatie van de IASs moeten worden gerealiseerd door middel wan een woorschrift waarin alle beursgenoteerde ondernemingen worden werplicht hun geconsolideerde jaarrekening op te stellen in owereenstemming met de IASs. De interpretatie van de IASs moet niet decentraal in de verschillende jurisdicdies plaatswinden, maar om wildgroei te voorkomen, centralal en wel door het SIC van het IASC.

Het toezicht op de naleving van de 1 ASs - het timpaan van de tempel - zou idealiter de vorm moeten aannemen van cen mechanisme dat erin voorziet dat wereldwijd een consistente interpretatie en toepassing wordt afgedwongen. Wierbij zouden thet accountantsberoep en de beurstoezichthouders een belangrijke rol moeten spelen. Binnen het accountantsberoep zijn al de eerste stappen genomen om te komen tot een adequate accountantscontrole en rapportering over de naleving van de IASs. In afwachting van een wereldwijde beurstoezichthouder zou het toezicht op de naleving binnen de Europese Unie moeten worden gecoördineerd. De Europese organisatie van beurstoezichthouders, de FESCO, zou in dit kader een centrale rol kunnen vervullen. 

Mijwher de Recror Magnificus.

Rest mij nog het dankwoord.

Het College van Bestuur van Universiteit Maastricht dank ik voor het in mij gestelde vertrouwen. Dit geldt ook voor de benoemingsadviescommissie en het bestuur van de Faculteit der Economische Wetenschappen \& Bedrijtskunde die bij mijn benoeming een belangrijke adviserende rol hebben gespeeld. Ik stel. het zeer op prijs een bijdrage te mogen leveren aan het onderwijs en onderzoek van deze succesvolle en door buitenstaanders bij herhaling hoogstgewaardeerde universiteit.

Hooggeleerde Buijink, beste Willem. Ik kan me nog als de dag van gisteren de nieuwjaarsreceptie van het Koninklijk NIVRA op 21 januari 1998 herinneren war jij mij hebt gevraagd of ik eventueel beschikbaar zou zijn voor een hoogleraarschap in Maastricht. Ik kan me ook nog het levendige e-mailverkeer voor de geest halen dat daarop volgde. Heel wat modellen zijn toen de revue gepasseerd. Ook jou dank ik woor het in mij gestelde vertrouwen en de moeite die jij aan de dag hebt gelegd om mij binnen te halen.

Hooggeleerde Maijoor, beste Steven. Ik dank jou voor de prettige samenwerking die we de afgelopen maanden al hebben gehad. Ik hoop dat we die in de toekomst verder kunnen uitbouwen. In het bijzonder wil ik jou als directeur van het Maastricht Accounting and Auditing Research and Education Center bedanken voor het organiseren van het symposium dat hedenmiddag ter gelegenheid van mijn inauguratie heeft plaatsgevonden.

De collegan's van de Sectie Accounting \& Auditing dank ik voor de prettige samenwerking en collegiale sfeer. Hoewel ik er in principe mar cén dag per week ben, heb ilk mij onmiddellijk thuis gevoeld. Rob Eken dank ik voor zijn hulp bij de werkzaamheden verbonden aan het opzetten en organiseren van het wak Intermational Financial Accomnting dat in de afgelopen blokperiode is gegeven. Annet Grol en Tanja Konings dank ik voor hun hulp bij de organisatie van het symposium en de inauguratie. 
Hooggeleerde Brink, beste Henk. Ik ben er trots op dat ik jou mag opvolgen in Maastricht. Langs deze weg wil ik jou hartelijk bedanken voor de brief die ik naar aanleiding van mijn benoeming van jou mocht ontvangen. Vooral de woorden aan het slot van de brief "zij hadden geen betere kunnen kiezen" deden mij deugd.

Hooggeleerde Klaassen, beste Jan. Als mijn promotor ben ik jou veel dank werschuldigd. Jij hebt aan de wieg gestaan van mijn academische loopbaan. In de jaren aan de Vrije Universiteit te Amsterdam heb ik wan jou ruim de gelegenheid gekregen om mij wetenschappelijk te ontplooien. Jouw commentaar en kritiek op mijn geschriften waren altijd constructief en bijzonder leerzaam. Jij hebt mij geleerd om de maatschappelijke relevantie van het wetenschappelijk onderzok niet uit het oog te verliezen.

Met mijn benoeming in Maastricht - nu acht maanden geleden - kwam een einde aan een bijna elfjarige periode waarin ik verbonden was aan de vakgroep Kosten-en Winstvraagstukken van de Vrije Universiteit te Amsterdam. Mijn oud-collega's dank ik voor de zeer plezierige jaren die ik daar heb gehad. In het bijzonder wil ik noemen, Kees Camfferman, Maarten Gelderman, Karel van Herwaarden, Peter Smidt, Elbert de With en Esther IJskes.

Professor Whittington. I would like to thank you very much for the participation in the symposium which was organised this afternoon.

Herr Doktor Biener. Ich bedanke mich auch bei Ihnen recht herzlich für thren Vortrag.

Hooggeleerde Van Helleman, beste Johan. Jij ook hartelijk dank voor jouw bijdrage aan het symposium.

De heer Dubbeld, beste Cees. Ook jou will ik niet ongenoemd laten in dit dankwoord. Ik heb veel van jou geleerd in de bijna drie jaar die wij bij het Koninklijk NIVRA hebben samengewerkt. Ik heb er nog dagelijks profijt van, niet alleen in mijn functie bij het Koninklijk NIVRA maar ook als wetenschapper. Bowendien heb ik jouw steun indertijd zeer gewaardeerd toen het een beetje minder dreigde te gaan met mijn academische carrière.

Ik clank mijn collega's bij het Koninklijk NIVRA voor het enthousiasme watmee zij mijn benoeming in Maastricht hebben ontvangen en de welgemeende interesse in mijn werk als wetenschapper. In het bijzonder dank ik de 
medewerkers van de afdeling Vaktechniek. Zonder jullie inzet flexibiliteit en loyaliteit zou het voor mij haast onmogelijk zijn mijn functie bij het Koninklijk NIVRA goed te combineren met een hoogleraarschap. Twee namen wil ik graag noemen: Jenny Dankbaar en Sylvia Woltjer. Jullie zijn mijn steun en toeverlaat. Ook de afgelopen weken wisten jullie mijn veelvuldige afwezigheid steeds in goede banen te leiden.

Ten slotte lrene. Voor jou de laatste twee woorden waarmee Mario Cavaradossi in de opera Tosca van de Italiaanse componist Giacomo Puccini de aria Recondita Amonia afsluit. Irene: "sei tu!" Twee kleine, doch alleszeggende woorden.

Zeer gewardeerde toehoorders.

Ik dank u voor uw aandacht.

Mi parolis.

Dat is Esperanto voor: Ik heb gezegd. 



\section{Literatuur}

American Accounting Association, Report on the American Accounting Association Committee on International Accounting Operations and Education 1975-1976, Accounting Review, supplement, 1977.

Amsterdam Exchanges, Consultatienota Primaire Markr, Amsterdam, 1999.

Cairns, D., Degrees of compliance, Accountancy International, september 1999.

Camfferman, K \& E. de With, Raad voor de Jaarverslaggeving: een tijd van komen en een tijd van gaan?, De Accountant, januari 1996.

Carsberg, B., The role and future plans of the International Accounting Standards Committee, Maandblad woor Accountancy en Bedrifseconomie, septenber 1999.

Certified General Accountants Association of Canada, The Case for International Accounting Standards in Canada, Vancouver, 1999.

Choi, F.D.S., C.A. Frost \& G.K. Meek, International Accouming, Prentice Hall, 1999.

Cooke, T.E., The Impact of Accounting Principles on Profits: The US versus Japan, Accounting and Business Research, herfst 1993.

Contactcomité Jaarrekeningenrichtlijnen, Een onderzoek naar de conformiteit tussen de internationale standaarden voor jaarrekeningen en de Europese jaarrekeningenrichnimen, Brussel, 1996.

Da Costa, R.C., J.C. Bourgeois \& W.M. Lawson, A Classification of Internathonal Financial Accounting Practices, International Journal of Accounting, lente 1978.

Documentatie rond de jaarrekening, losbladige uitgave bijgewerkt tot en met aflevering 65 (mei 1999), Kluwer.

Doupnik, T.S. \& S.B. Salter, External Environment, Culture, and Accounting Practice: A Priliminary Test of a General Model of International Accounting Development, International Joumal of Accounting, nummer 3, 1995. 
Europese Commissie, Mededeling van 14 november 1995 betreffende de harmonisatie van de jaarrekeningen: cen miewwe strategie ten anzien van internationale harmonisatie, Brussel, 1995.

Europese Commissie, Financial Services: building a franework for action. Brussel, 1998.

Europese Commissie, Implementing the framework for financial markets: action plan, Brussel, 1999 (a).

Europese Commissie, Examination of the conformity between International Accounting Standards and the European Accounting Directives, Brussel, 1999 (b).

FASB, The IASC-U.S. Comparison Project: A Report on the Similarities and Differences between $I A S C$ Standards and U.S. GAAP, Norwalk (Connecticut), 1996.

FASB, Intemational Accounting Standard Setting: A Vision for the Future, 1999.

FEE, Comparison of the EC Accounting Directives and LASs: A contribution to international accounting developments, Brussel, 1999(a).

FEE, Discussion Paper on a Financial Reporting Strategy within Europe, oktober $1999(\mathrm{~b})$.

Frank, W.G., An Empirical Analysis of International Accounting Principles, Journal of Accounting Research, herfst 1979.

Gray, S.J., Towards a Theory of Cultural Influence on the Development of Accounting Systems Internationally, Abcacus, maart 1988.

Helleman wan, J. \& J. Klatassen, Betekenis van internationale standaarden voor de Nederlandse wet- en regelgeving. Maandblad voor Accountancy en Bedriffseconomie, september 1999.

Hellman, N., A Comparative Analysis of the Impact of Accounting Differences on Prolits and Return on Equity: Differences between Swedish Practice and US GAAP, European Acounting Review, nummer 3, 1993.

Hulle van, K, IOSCO Endorsement: A European perspective, Maandblad woor Acconntancy en Bedrifseconomie, september 1999.

IASC, Shaping IASC for the Future, december 1998. 
IASC, Internarional Accownting Standards 1999, 1999.

Leder, P, IOSCO Assessment: A view from within, Maandblad woor Accountancy en Bedrifseconomie, september 1999.

McGregor, W, An Insider's View of the Current State and Future Direction of International Accounting Standard Setting, Accounting Horizons, juni 1999.

Mueller, G.G., International Accounting, Macmillan, 1967.

Mueller, G.G., Accounting Principles Generally Accepted in the United States versus Those Generally Accepted Elsewhere, Imternational Journat of Accomating, lente 1968.

Nair, R.D. \& W.G. Frank, The Impact of Disclosure and Measurement Practices on International Accounting Classifications, Accounting Review, juli 1980.

Nobes, C.. A Judgmental International Classification of Financial Reporting Practices, Joumal of Business Finance and Accounting, lente 1983.

Nobes, C., Towards a General Model of the Reasons for International Differences in Financial Reporting, Abacus, nummer 2, 1998.

Nobes, C. \& R. Parker, Comparative Intemational Accounting, Prentice Hall, 1998.

Pacter, P., International Accounting Standards: The world's standards by 2002 , CPA Journal, juli 1998.

Radebaugh, L.H. \& S.J. Gray, International Accounting and Multinational Enterprises, Wiley, 1997.

Rechtspersonen, tab 9 Jaarrekening, losbladige uitgave bijgewerkt tot en met supplement 143 (maart 1998), Kluwer.

Seidler, L.J., International Accounting - The Ultimate Theory Course, Accounting Review, oktober 1967.

Steenbeek, O, De Beurs van Europa, Bank-en Effectenbedrijf, januari/februari 1999.

Street, D.L., S.J. Gray \& S.M. Bryant, Acceptance and Observance of International Accounting Standards: An Empirical Study of Companies Claiming to Comply with IASs, International Joumal of Accountivg, nummer I, 1999. 
Tas van der, L.G. De invloed van IAS op Europa en vice versa een titanenstrijd?, in: A.J. Bindenga, M.A. wan Hoepen J. Mat (redactie), Bericht gegeven: opstellenbundel aangeboden aan prof.drs. F. Krens, Kluwer, 1999.

Traas, L., Om de kwaliteit van de Nederlandse jaarverslaggeving: Nederland blijft ver achter bij internationale "best practice", Management Control \& Accounting, april/mei 1999.

Vergoossen, R.G.A., Rapportering "on Form 20-F': Effecten van verschillen uussen Nederlandse en Amerikaanse verslaggevingsgrondslagen, Maandblad voor Accountancy en Bedrijsseconomie, oktober 1991.

Vergoossen, R.G.A., Invloed US GAAP op eigen vermogen en nettoresultaat van Nederlandse ondernemingen, Jaar in-jaar uit 9 , onder redactie van H.L. Brink en L.G. van der Tas, Kluwer, 1995.

Vergoossen, R.G.A., Invloed beursnotering in Verenigde Staten op stelselkeuze en additionele informatieverschaffing, Masasublad voor Accoumtancy en Bedriffseconowie, november 1996.

Vergoossen, R.G.A. Prof.dr J. van Helleman RA, voorzitter van de Raad voor de Jaarverslaggeving: "Op nationaal niveau moet je een eigen regelgevend orgaan hebben", De Accoumtant, oktober 1997.

Vergoossen, R.G.A., Nederlandse cijfers onder US GAAP: de vrije oefening en het strenge regiem, Managenent Control \& Accounting, april 1998.

Vergoossen, R.G.A., IASC quo vadis?, de Accoumtant, februari 1999(a).

Vergoossen, R.G.A., Balanceren met goodwill, de Accountant, september $1999(\mathrm{~b})$.

Vergoossen, R.G.A., Heef het IASC nog een toekomst?, de Accountant, september 1999(c).

Vergoossen, R.G.A. International Accounting Standards en cle gevolgen voor de jaarverslaggeving in Nederland, Maandblad woor Acountancy en Bedrifseco. nomie, september 1999 (d).

Vergoossen, R.G.A. \& A.A.R. Polman, US GAAP en de jaarverslaggeving van Nederlandse ondernemingen. Maandblad noor Accountancy en Bedriffseconowire, september 1995. 
VNO-NCW, Mtemationale verslaggevingsregels in Nederland toepasbaar?: analyse en enquête, Den Haag, 1998.

Weetman, P. \& S.J. Gray, International Financial Analysis and Companative Corporate Performance: The Impact of UK versus US Accounting Principles on Eamings, Joumal of lnternational Financial Management and Accowting. nummer 2/3, 1990.

Weetman, P. S.J. Gray, A Comparative International Analysis of the Impact of Accounting Principles on Profits: The USA versus the UK, Sweden and The Netherlands, Accounting and Business Research, herfst 1991.

Wel van der, F., RJ: de tijd van gaan niet gekomen!, De Accmunant, januari 1996.

Zanden van der, P.M., De illusie van de internationale regelgeving rondom verslaggeving, de Accountani, januari 1999. 
561 Afkoringen

\section{Lijst van gebruikte afkortingen}

FASB Financial Accounting Standards Board

FEE

FESCO

Fédération des Experts Comptables Européens

IAS(s)

Forum of European Securities Commissions

IASC

International Accounting Standard(s)

IFAC

International Accounting Standards Cormmittee

$105 C O$

International Federation of Accountants

ISAs

International Organization of Securities Commissions

International Standards on Auditing

Koninklijk NIVRA Koninklijk Nederlands Instituut van Registeraccountants

RAC

Richtlininen voor de Accountantscontrole

$\mathrm{RJ}$

Raad woor de Jaarverslaggeving.

RJ-richtlijnen

Richthlijnen woor de jaarverslaggeving

SDC

Standards Development Committee

SEC

Securities and Exchange Commission

SIC

Standing Interpretations Committee

US GAAP

United States Generally Accepted Accounting Principles 


\section{International Accounting Standards: Esperanto or a Tower of Babel?}

Summary in English of inaugural lecture

$$
\text { given by }
$$

$$
\text { Dr. R.G.A. Vergoossen RA }
$$

on the occasion of his appointment as Professor of International Financial Accounting at Universiteit Maastricht on Friday 29 October 1999 

In 1995 the International Accounting Standards Committee (IASC) agreed with the International Organization of Securities Commissions (1OSCO) to develop a core set of standards. If the completed core set of standards satisfies IOSCO, it will consider recommendiag endorsement of the International Accounting Standards (IASs) to its members for use by foreign issuers in crossborder listings and offerings. In December 1999 IASC will most probably complete its core set of standards. IOSCO has already started its assessment of IASs. A recommendation by IOSCO to its members to endorse IASs would be of significant importance to IASC. However, this would not be the end of the process of LASC becoming the global standard-setter.

A comprehensive set of high quality standards alone is not enough for IASC to become the global standard-setter. Critically important for IASC are:

- the standard-setting process of IASC;

- the implementation of IASs: and

- the enforcement of IASs.

At the moment these three elements are not settled satisfactorily and consequently represent obstacles towards IASC becoming the global standard-setter and its standards becoming the "Esperanto of financial accounting and report" ing". The analogy of the façade of a Greek temple is used to visualise how the three elements identified above relate to each other.

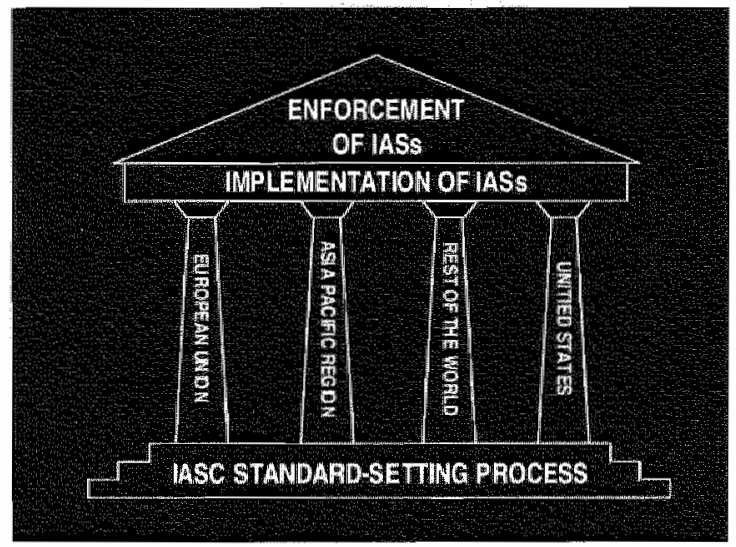

Figure The AASC Teminge 


\section{IASC standard-setting process}

The standard-setting process of LASC should be acceptable to jurisdictions and countries. The current structure of IASC is not acceptable anymore to important constituents involved in international accounting standard-setting. In 1997 the IASC Board formed a Strategy Working Party (SWP) to consider what IASC's strategy and structure should be.

In the discussion paper "Shaping IASC for the Future", issued in December 1998, the SWP proposed a bicameral system for making decisions about IASs. IASC would establish a Standards Development Committee (SDC) to work alongside an extended Board. Most of the members of the SDC would represent national standard-setters and work full-time on standard-setting. This model was strongly criticised, because it could be a source of conflict and delay and because of different views about the powers of both the SDC and the Board.

Last Summer the main features of a new proposal were outlined. It was suggested to have a unicameral system comprising a Board made up of individuals, appointed in their own right rather than as representatives of countries or organisations. However, to gain enough support there should be a geographical balance and a balance of background experience. A majority of the Board. members should work full-time for IASC. The new proposal is a step in the right direction that should be pursued.

The standard-setting process is the foundation of the temple. If there is not enough support for the standard-setting process of IASC, the questions on the implementation and enforcement of IASs do not arise. Without a sound foundation the temple will collapse.

\section{Implementation of IASs}

The way and the extent to which IASs are adopted or implemented vary considerably around the world. Consequently, the interpretation and application of lASs might diverge between countries or jurisdictions. Thus there is a danger that IASs eventually result in a Tower of Babel.

Ideally, the implementation of IASs should be co-ordinated world-wide. With respect to the implementation of $\mathrm{LASs}$, four countries or regions are distinguished, viz. the European Union, the United States, the Asia Pacific region and the rest of the world. They are the pillars of the temple. Implementation of IASs in the European Union and the United States - the outside pillars - are considered to be essential for IASC in becoming the global standard-setter and 
its standards in becoming the "world language". If one of the outside pillars is missing, the temple will be unstable. The inner pillars - the Asia Pacific region and the rest of the world - are not essential to keep the temple standing. In order to arrive at an "Esperanto of financial accounting and reporting", being IASs, the support and commitment of the European Union and the United States are of vital importance. Other parts of the world will probably follow in due course.

At the moment it is unclear whether the U.S. Securities and Exchange Commission (SEC) will endorse IASs for foreign listings and offerings. SEC is wery reluctant to do so. An endorsement of IASs for domestic listings and offerings is not under consideration.

In the European Union all listed companies should be required to use IASs instead of national accounting standards in the consolidated accounts, provided that the new structure of the standard-setting process is satisfactory to the European Union. Furthermore, a new European body should be established to promote the understanding and use of IASs in the European Union. However, it should not act as a "European" interpretations committee. IASC's Standing Interpretations Committee interprets IASs on a world-wide basis.

\section{Enforcement of IASs}

An acceptable standard-setting process and the implementation or adoption of IASs are not sufficient if LASs are to become the "world language". If companies are required to conply with IASs and to apply them consistently, there should be an enforcement mechanism, the tympanum of the temple.

The accountancy profession and the securities commissions have an important role to play concerning the enforcement of IASs. However, the quality of the accountancy profession and the role of securities commissions differ considerably around the world.

The accountancy profession should pursue the objective of ensuring that, on a world-wide basis, audited financial statements meet certain minimum requirements. The securities commissions, especially within the European Union, should co-ordinate then activities. Ideally, a European SEC should be estalblished. 